Lawrence Livermore National Laboratory

Emergency Response Capability

Baseline Needs Assessment

Requirement Document

J. A. Sharry

January 4, 2010 
This document was prepared as an account of work sponsored by an agency of the United States government. Neither the United States government nor Lawrence Livermore National Security, LLC, nor any of their employees makes any warranty, expressed or implied, or assumes any legal liability or responsibility for the accuracy, completeness, or usefulness of any information, apparatus, product, or process disclosed, or represents that its use would not infringe privately owned rights. Reference herein to any specific commercial product, process, or service by trade name, trademark, manufacturer, or otherwise does not necessarily constitute or imply its endorsement, recommendation, or favoring by the United States government or Lawrence Livermore National Security, LLC. The views and opinions of authors expressed herein do not necessarily state or reflect those of the United States government or Lawrence Livermore National Security, LLC, and shall not be used for advertising or product endorsement purposes.

This work performed under the auspices of the U.S. Department of Energy by Lawrence Livermore National Laboratory under Contract DE-AC52-07NA27344. 


\section{Emergency Response Capability Baseline Needs Assessment}

\section{Requirements Document}

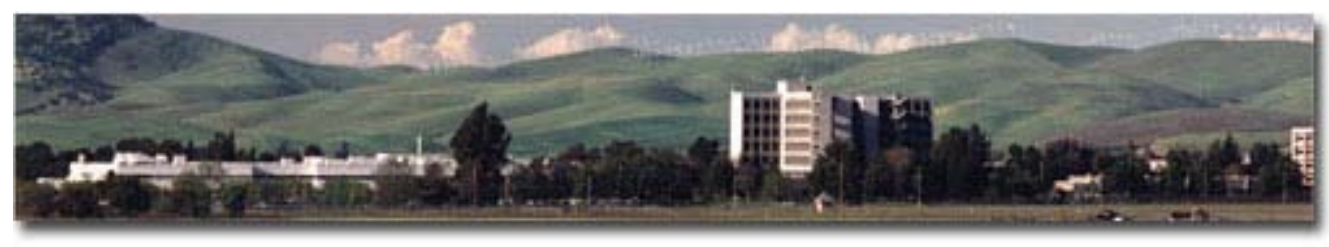

Lawrence Livermore National Laboratory

December 2009 
SIGNATURE PAGE

\section{Lawrence Livermore National Laboratory Sandia National Laboratory/CA}

\section{9 \\ Emergency Response Capability BASELINE NEEDS ASSESSMENT Requirements Document}

Revision 6.0

December 2009

Revised January 2010
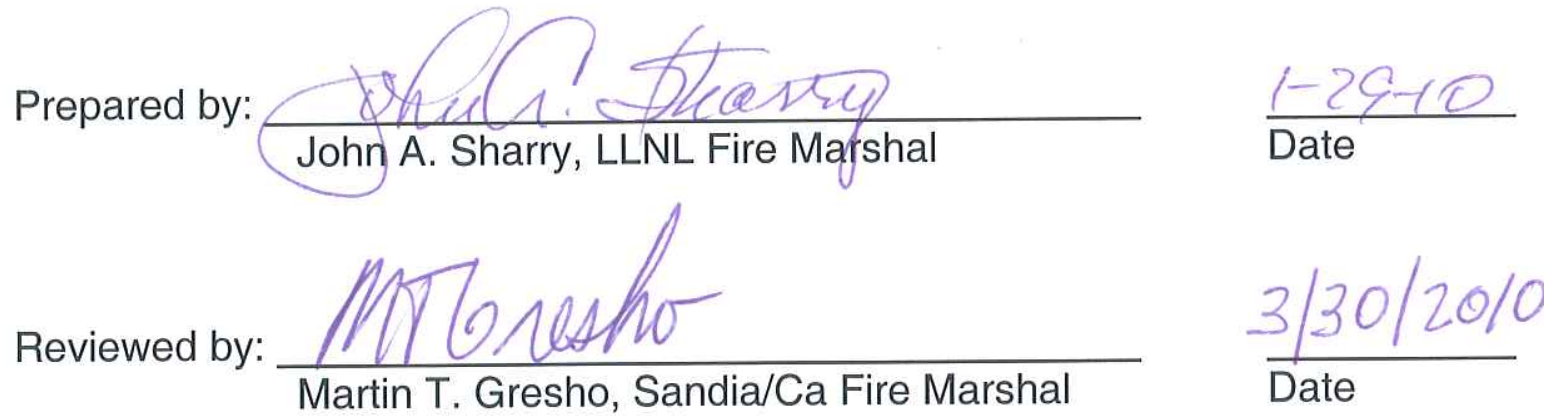


\section{Table of Contents}

1 Introduction and Executive Summary............................................................................6

$1.1 \quad$ Introduction.............................................................................................

$1.2 \quad$ Executive Summary of Baseline Needs ................................................................

1.2.1 Requirements Summary - Structural Fire Fighting............................................

1.2.2 Requirements Summary - Wildland Fire Fighting.........................................

1.2.3 Requirements Summary - Emergency Medical Service ....................................9

1.2.4 Requirements Summary Hazardous Materials...................................................9

1.2.5 Requirements Summary Technical Rescue ...................................................9

1.2.6 Requirements Summary - Emergency Communication and Dispatch ..........10

1.2.7 Requirements Summary - Training and Certification......................................10

1.2.8 Requirements Summary - Pre-Fire Plans........................................................11

1.2.9 Requirements Summary - Emergency Response Apparatus ..........................11

2 Assumptions.....................................................................................................................11

3 Scope....................................................................................................................12

4 Site Description ...........................................................................................................................12

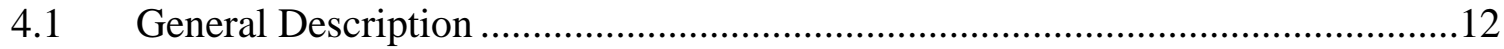

5 Requirement and Guidance Documents ........................................................................14

$5.1 \quad$ Requirement Documents..............................................................................14

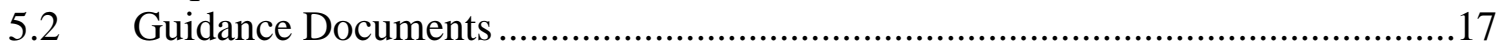

$6 \quad$ Primer on Terminology ..............................................................................................17

7 Determination on Minimum Response Requirements .................................................19

7.1 Structural Fire Fighting ................................................................................20

7.1.1 Structural Fire Fighting - Site 200 (LLNL Livermore and SANDIA/CA) ..20

7.1.2 Structural Fire Fighting - Site 300.............................................................26

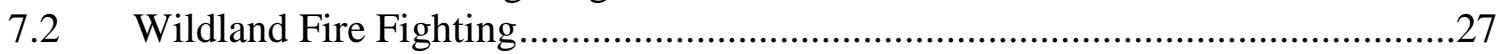

7.2.1 Wildland Fire Fighting - Site 200 (LLNL Livermore \& Sandia/CA)..........27

7.2.2 Wildland Fire Fighting - Site 300 .................................................................29

7.3 Emergency Medical Service (EMS) Requirements ...............................................30

7.3.1 Determination of Minimum Response Requirements - EMS ........................30

7.3.2 Minimum Requirements - EMS .....................................................................31

7.3.3 Requirements Summary -- EMS .......................................................................31

7.4 Hazardous Materials (HAZMAT) Response Requirements ...................................31

7.4.1 Determination of Minimum Response Requirements - HAZMAT ...............31

7.4.2 Minimum Requirements - HAZMAT …………........................................34

7.4.3 Requirements Summary - HAZMAT..............................................................34

7.5 Technical Rescue Response Requirements.............................................................34

7.5.1 Determination of Minimum Requirements - Technical Rescue......................34

7.5.2 Minimum Requirements - Technical Rescue ...................................................35

7.5.3 Requirements Summary - Technical Rescue ..................................................35

7.6 Emergency Communication and Dispatch Requirements ......................................36

7.6.1 Determination of Minimum Requirements - Emergency Communications 36

7.6.2 Minimum Requirements - Emergency Communications ................................37

7.6.3 Requirements Summary - Emergency Communications ................................38

7.7 Training and Certification.....................................................................................38 
7.7.1 Determination of Minimum Requirements - Training ..............................38

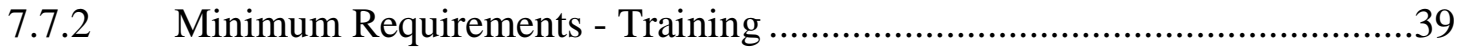

7.7.3 Requirements Summary - Training ....................................................40

$7.8 \quad$ Pre-Fire Plan Requirements .....................................................................40

7.8.1 Determination of Minimum Requirements - Pre-Fire Plans ......................40

7.8.2 Minimum Requirements - Pre-Fire Plans.................................................41

7.8.3 Requirements Summary - Pre-Fire Plans ..............................................41

7.9 Emergency Response Apparatus Requirements ..............................................41

7.9.1 Determination of Minimum Response Requirements - Apparatus ..............41

7.9.2 Minimum Requirements - Apparatus ................................................45

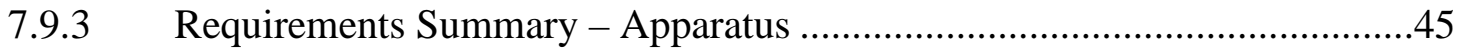

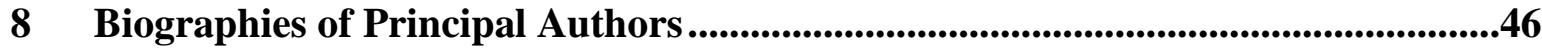




\section{List of Acronyms}

ACRECC Alameda County Regional Emergency Communication Center

AED

AHJ

ALS

BLS

BNA

CAS

DOE

DOT

ECC

EMS

EOC

LLNL

NFPA

SNL/CA
Automated External Defibrillator

Authority Having Jurisdiction

Advanced Life Support

Basic Life Support

Baseline Needs Assessment

Central Alarm Station

Department of Energy

Department of Transportation

Emergency Communication Center

Emergency Medical System

Emergency Operations Center

Lawrence Livermore National Laboratory

National Fire Protection Association

Sandia National Laboratories - California 


\section{Introduction and Executive Summary}

\subsection{Introduction}

This revision of the LLNL Fire Protection Baseline Needs Assessment (BNA) was prepared by John A. Sharry, LLNL Fire Marshal and LLNL Division Leader for Fire Protection and reviewed by Martin Gresho, Sandia/CA Fire Marshal. The document follows and expands upon the format and contents of the DOE Model Fire Protection Baseline Capabilities Assessment document contained on the DOE Fire Protection Web Site, but only address emergency response. ${ }^{1}$

The original LLNL BNA was created on April 23, 1997 as a means of collecting all requirements concerning emergency response capabilities at LLNL (including response to emergencies at Sandia/CA) into one BNA document. The original BNA documented the basis for emergency response, emergency personnel staffing, and emergency response equipment over the years. The BNA has been updated and reissued five times since in 1998, 1999, 2000, 2002, and 2004.

A significant format change was performed in the 2004 update of the BNA in that it was "zero based." Starting with the requirement documents, the 2004 BNA evaluated the requirements, and determined minimum needs without regard to previous evaluations. This 2010 update maintains the same basic format and requirements as the 2004 BNA. In this 2010 BNA, as in the previous BNA, the document has been intentionally divided into two separate documents - the needs assessment (1) and the compliance assessment (2). The needs assessment will be referred to as the BNA and the compliance assessment will be referred to as the BNA Compliance Assessment. The primary driver for separation is that the needs assessment identifies the detailed applicable regulations (primarily NFPA Standards) for emergency response capabilities based on the hazards present at LLNL and Sandia/CA and the geographical location of the facilities. The needs assessment also identifies areas where the modification of the requirements in the applicable NFPA standards is appropriate, due to the improved fire protection provided, the remote location and low population density of some the facilities. As such, the needs assessment contains equivalencies to the applicable requirements. The compliance assessment contains no such equivalencies and simply assesses the existing emergency response resources to the requirements of the BNA and can be updated as compliance changes independent of the BNA update schedule.

There are numerous NFPA codes and standards and other requirements and guidance documents that address the subject of emergency response. These requirements documents are not always well coordinated and may contain duplicative or conflicting requirements or even coverage gaps. Left unaddressed, this regulatory situation results in frequent interpretation of requirements documents. Different interpretations can then lead to inconsistent implementation. This BNA addresses this situation by compiling applicable requirements from all identified sources (see Section 5) and analyzing them collectively to address conflict and overlap as applicable to the hazards presented by the LLNL and Sandia/CA sites (see Section 7). The BNA also generates requirements when needed to fill any identified gaps in regulatory coverage. Finally, the BNA produces a customized 
simple set of requirements, appropriate for the DOE protection goals, such as those defined in DOE O 420.1B, the hazard level, the population density, the topography, and the site layout at LLNL and Sandia/CA that will be used as the baseline requirements set - the "baseline needs" - for emergency response at LLNL and Sandia/CA. A template approach is utilized to accomplish this evaluation for each of the nine topical areas that comprise the baseline needs for emergency response. The basis for conclusions reached in determining the baseline needs for each of the topical areas is presented in Sections 7.1 through 7.9.

This BNA identifies only mandatory requirements and establishes the minimum performance criteria. The minimum performance criteria may not be the level of performance desired Lawrence Livermore National Laboratory or Sandia/CA. Performance at levels greater than those established by this document will provide a higher level of fire safety, fire protection, or loss control and is encouraged.

In Section 7, Determination of Baseline Needs, a standard template was used to describe the process used that involves separating basic emergency response needs into nine separate services. Each service being evaluated contains a determination of minimum requirements, an analysis of the requirements, a statement of minimum performance, and finally a summary of the minimum performance.

The requirement documents, listed in Section 5, are those laws, regulations, DOE Directives, contractual obligations, or LLNL policies that establish service levels. The determination of minimum requirements section explains the rationale or method used to determine the minimum requirements. The minimum performance measure describes a method for evaluating if the minimum requirements are being met. The requirement summary states the minimum requirement without explanation or justification.

On October 1, 2007, LLNL contracted with the Alameda County Fire Department to provide emergency response services. While that was a significant milestone in fire suppression and emergency services at LLNL, it has little impact on the BNA. The level of service called for in the contract with Alameda County is driven by the baseline needs as identified in the 2004 BNA and are essentially the same as was provided by the LLNL Fire Department.

\subsection{Executive Summary of Baseline Needs}

This section provides a listing of the results of this baseline needs assessment for the assessed elements of emergency response. Because total response time (which includes dispatch time, turnout time, and travel time) is a more comprehensive metric than just travel time, this analysis will use total response time for all evaluations.

\subsubsection{Requirements Summary - Structural Fire Fighting}

The structural firefighting requirements for LLNL Site 200 (including Sandia/CA) and for LLNL Site 300 are reported separately due primarily to geographical differences between the two sites that impact response times 


\subsubsection{Requirements Summary - Structural Fire Fighting - LLNL Site 200 and Sandia/CA}

Table 1.2.1.1 Requirements Summary - Structural Fire Fighting - Site 200 \& Sandia/CA

\begin{tabular}{|c|c|c|c|c|}
\hline Type Incident & Responders & $\begin{array}{c}\text { Minimum } \\
\text { Staffing } \\
\text { (persons) }\end{array}$ & $\begin{array}{c}\text { Total } \\
\text { Response } \\
\text { Time }\end{array}$ & $\begin{array}{c}\text { Performance } \\
\text { Criteria }\end{array}$ \\
\hline \multirow{2}{*}{ Structure Fire } & $1^{\text {st }}$ Unit & 4 & 380 & $90 \%$ \\
\cline { 2 - 5 } & Remainder of $1^{\text {st }}$ Alarm & 5 & 620 & $90 \%$ \\
\hline
\end{tabular}

\subsubsection{Requirements Summary - Structural Fire Fighting - LLNL Site $\mathbf{3 0 0}$}

Table 1.2.1.2 Requirements Summary - Structural Fire Fighting - LLNL Site 300

\begin{tabular}{|l|l|c|c|c|}
\hline \multirow{2}{*}{ Type Incident } & \multicolumn{1}{|c|}{ Responders } & $\begin{array}{c}\text { Minimum } \\
\text { Staffing } \\
\text { (persons) }\end{array}$ & $\begin{array}{c}\text { Total } \\
\text { Response } \\
\text { Time }\end{array}$ & $\begin{array}{c}\text { Performance } \\
\text { Criteria }\end{array}$ \\
\hline GSA Area & $1^{\text {st }}$ Unit & 4 & $380 \mathrm{sec}$. & $90 \%$ \\
\cline { 2 - 5 } Structure Fire & Remainder of $1^{\text {st }}$ Alarm & 5 & $1800 \mathrm{sec}$. & $90 \%$ \\
\hline $\begin{array}{l}\text { Non GSA Area } \\
\text { Structure Fire }\end{array}$ & $1^{\text {st }}$ Unit & 4 & $960 \mathrm{sec}$. & $90 \%$ \\
\cline { 2 - 5 } & Remainder of $1^{\text {st }}$ Alarm & 5 & $2760 \mathrm{sec}$. & $90 \%$ \\
\hline
\end{tabular}

\subsubsection{Requirements Summary - Wildland Fire Fighting}

The wildland firefighting requirements for LLNL Site 200 (Livermore) and for LLNL Site 300 are reported separately due primarily to geographical differences between the two sites that impact response times.

\subsubsection{Requirements Summary - Wildland Fire Fighting LLNL Site 200 \& Sandia/CA}

Table 1.2.2.14 Requirements Summary - Wildland Fire Fighting Site 200 (LLNL Livermore and Sandia/CA)

\begin{tabular}{|c|c|c|c|c|}
\hline \multirow{2}{*}{ Type Incident } & Responders & $\begin{array}{c}\text { Minimum } \\
\text { Staffing } \\
\text { (persons) }\end{array}$ & $\begin{array}{c}\text { Total } \\
\text { Response } \\
\text { Time }\end{array}$ & $\begin{array}{c}\text { Performance } \\
\text { Criteria }\end{array}$ \\
\hline \multirow{2}{*}{ Wildland Fire } & $1^{\text {st }}$ Units & 4 & 440 & $90 \%$ \\
\cline { 2 - 5 } & Remainder of $1^{\text {st }}$ Alarm & 1 & 620 & $90 \%$ \\
\hline
\end{tabular}




\subsubsection{Requirements Summary - Wildland Fire Fighting LLNL Site $\mathbf{3 0 0}$}

Table 1.2.2.2 Requirements Summary - Wildland Fire - Site 300

\begin{tabular}{|l|l|c|c|c|}
\hline \multicolumn{1}{|c|}{ Type Incident } & Responders & $\begin{array}{c}\text { Minimum } \\
\text { Staffing } \\
\text { (persons) }\end{array}$ & $\begin{array}{c}\text { Total } \\
\text { Response } \\
\text { Time }\end{array}$ & $\begin{array}{c}\text { Performance } \\
\text { Criteria }\end{array}$ \\
\hline Wildland Fire & Fire Attack & 4 & 1020 sec. & $90 \%$ \\
Battalion Chief & $\underline{1}$ & 2760 sec. & $90 \%$ \\
\hline
\end{tabular}

\subsubsection{Requirements Summary - Emergency Medical Service}

Table 1.2.3 Requirements Summary - EMS

\begin{tabular}{|c|c|c|c|}
\hline Type Incident & Responders & $\begin{array}{c}\text { Minimum } \\
\text { Staffing } \\
\text { (persons) }\end{array}$ & $\begin{array}{c}\text { Response } \\
\text { Time }\end{array}$ \\
\hline $\begin{array}{c}\text { All EMS } \\
\text { Except Site 300 Non GSA }\end{array}$ & $1^{\text {st }}$ Responder/Transport & $\begin{array}{c}1 \mathrm{ALS} \\
2 \mathrm{BLS}\end{array}$ & $480 \mathrm{sec}$. \\
\hline $\begin{array}{c}\text { EMS } \\
\text { Site 300 Non GSA }\end{array}$ & $1^{\text {st }}$ Responder/Transport & $\begin{array}{c}1 \mathrm{ALS} \\
2 \mathrm{BLS}\end{array}$ & $900 \mathrm{sec}$. \\
\hline
\end{tabular}

\subsubsection{Requirements Summary Hazardous Materials}

Table 1.2.4 Requirements Summary - HAZMAT

\begin{tabular}{|c|c|c|}
\hline Task & Staffing & Training Level \\
\hline \multicolumn{3}{|c|}{ Investigation Level Incident } \\
\hline Incident Commander & 1 & Hazmat IC \& Technician \\
\hline Total & 4 & 380 sec. $90 \%$ of the time \\
\hline \multicolumn{3}{|c|}{ Level I Incident Site 200 Only } \\
\hline Incident Commander & 1 & Hazmat IC \& Specialist \\
\hline Safety and Tech Reference & 2 & HM Safety and Technician \\
\hline HazMat Group & 7 & Technician \\
\hline Medical Group & 2 & Operations \& EMT \\
\hline Total & 12 & 680 sec. $90 \%$ of the time \\
\hline \multicolumn{3}{|c|}{ Level II Incident } \\
\hline Incident Commander & 1 & Hazmat IC \& Specialist \\
\hline Safety and Tech Reference & 3 & Specialists \& Technicians \\
\hline HazMat Group & 9 & Technician \& Operations \\
\hline Time Recorder \& Access Control & 2 & Operations \\
\hline Medical Group & 2 & Operations and EMT \\
\hline Total & 17 & \\
\hline
\end{tabular}

\subsubsection{Requirements Summary Technical Rescue}

Table 1.2.5 Requirements Summary - Technical Rescue 


\begin{tabular}{|c|l|c|c|c|}
\hline \multicolumn{1}{|c|}{ Type Incident } & Responders & $\begin{array}{c}\text { Minimum } \\
\text { Staffing } \\
\text { (persons) }\end{array}$ & $\begin{array}{c}\text { Total } \\
\text { Response } \\
\text { Time }\end{array}$ & $\begin{array}{c}\text { Performance } \\
\text { Criteria }\end{array}$ \\
\hline $\begin{array}{c}\text { S-200, Sandia/CA } \\
\begin{array}{c}\text { S-300 GSA Area } \\
\text { Technical Rescue }\end{array}\end{array}$ & $1^{\text {st }}$ Unit & 4 & 380 sec. & $90 \%$ \\
\cline { 2 - 5 } $\begin{array}{l}\text { Non GSA Area } \\
\text { Technical Rescue }\end{array}$ & $1^{\text {st }}$ Unit & 5 & 1800 sec. & $90 \%$ \\
\cline { 2 - 5 } & Remainder of $1^{\text {st }}$ Alarm & 5 & 2760 sec. & $90 \%$ \\
\hline
\end{tabular}

\subsubsection{Requirements Summary - Emergency Communication and Dispatch}

Table 1.2.6 Requirements Summary - Emergency Communications

\begin{tabular}{|l|c|c|}
\hline \multicolumn{1}{|c|}{ Event } & Time Criteria & Performance \\
\hline Dispatcher training & N/A & NFPA 1061 \\
\hline ACRECC Answer or & 15 seconds & $95 \%$ \\
Acknowledge Alarm & 40 seconds & $99 \%$ \\
\hline ACRECC Dispatch & 60 seconds & $95 \%$ \\
Emergency & 90 seconds & $99 \%$ \\
\hline Lab Alarms transmit alarms to & 45 seconds & $95 \%$ \\
ACRECC & & \\
\hline $\begin{array}{l}\text { ACRECC and/or Lab Alarms } \\
\text { Notify Appropriate Party of } \\
\text { Supervisory or Trouble Alarm }\end{array}$ & 600 seconds & $95 \%$ \\
\hline
\end{tabular}

\subsubsection{Requirements Summary - Training and Certification}

Table 1.2.7 Requirements Summary - Training

\begin{tabular}{|l|l|}
\hline \multicolumn{1}{|c|}{ Personnel } & \multicolumn{1}{c|}{ Performance Measure } \\
\hline Entry level & $\begin{array}{l}\text { Qualifications are established for entry-level fire } \\
\text { department personnel that include medical and } \\
\text { physical performance criteria. }\end{array}$ \\
\hline Entry level & $\begin{array}{l}\text { There is an established training criterion for } \\
\text { minimum performance of entry-level personnel. }\end{array}$ \\
\hline Incumbents & $\begin{array}{l}\text { There is an established on-going training criterion } \\
\text { for training for incumbents. }\end{array}$ \\
\hline Officers & $\begin{array}{l}\text { There is a minimum training criteria established for } \\
\text { fire officers or supervisors of emergency responder. }\end{array}$ \\
\hline Special Operations & $\begin{array}{l}\text { There is a minimum training criteria established for } \\
\text { special operations such as hazardous materials and } \\
\text { technical rescue. }\end{array}$ \\
\hline Drills and Exercises & $\begin{array}{l}\text { There is an established program of drills and } \\
\text { exercises at various facilities on LLNL site. }\end{array}$ \\
\hline All & $\begin{array}{l}\text { Documented training records exist for each } \\
\text { individual. }\end{array}$ \\
\hline
\end{tabular}




\subsubsection{Requirements Summary - Pre-Fire Plans}

Table 1.2.8 Requirements Summary - Pre-Fire Plans

\begin{tabular}{|l|c|}
\hline \multicolumn{1}{|c|}{ Performance Measure } & Update Frequency \\
\hline Provide pre-fire plans for all buildings & Semi-Annual \\
\hline $\begin{array}{l}\text { Provide written standard operating procedures for } \\
\text { response to occupancies with hazardous materials or } \\
\text { other unique hazards }\end{array}$ & $\begin{array}{l}\text { Review Annually - } \\
\text { Update as Needed. }\end{array}$ \\
\hline $\begin{array}{l}\text { Ensure that Emergency Call Out Lists and Special } \\
\text { Information Sheets are updated by ES\&H Teams. }\end{array}$ & Quarterly \\
\hline
\end{tabular}

\subsubsection{Requirements Summary - Emergency Response Apparatus}

Table 1.2.9 Requirements Summary - Emergency Response Apparatus

Provide the following apparatus for use by the Fire Department at LLNL:

\begin{tabular}{|l|c|l|}
\hline \multicolumn{1}{|c|}{ Type Apparatus } & Number & \multicolumn{1}{c|}{ Comment } \\
\hline Engine & 3 & Livermore Site - 2, S-300-1 \\
\hline Aerial Ladder & 1 & Livermore Site \\
\hline $\begin{array}{l}\text { Ambulance ALS } \\
\text { Configuration }\end{array}$ & 2 & Livermore Site - 1, S-300-1 \\
\hline Type 3 Engine & 2 & Livermore Site - 1, S-300-1 \\
\hline Type 4 Engine & 2 & Livermore Site - 1, S-300-1 \\
\hline Hazardous Materials & 1 & Responds both sites \\
\hline Command & 1 & Battalion Chief \\
\hline Reserve Type 1Engine & 1 & 1 Reserve per 5 in front-line service \\
\hline Reserve Ambulance & 1 & 1 Reserve per 5 in front-line service \\
\hline Reserve Type 3 Engine & 1 & 1 Reserve per 5 in front-line service \\
\hline Reserve Type 4 Engine & 1 & 1 Reserve per 5 in front-line service \\
\hline
\end{tabular}

\section{Assumptions}

In developing this assessment, the following assumptions were made:

a. That LLNL and Sandia/CA acknowledge an assumption of risk commensurate with emergency response and standard industry practices.

b. In developing the necessary response capability, the BNA applies only the DOE requirements and those requirements of referenced DOE documents.

c. This BNA is based on the accuracy of information, documents, and data provided to the author from LLNL, Sandia/CA, and the Alameda County Fire Department.

d. That all fire suppression and alarm systems are maintained in operational condition per NFPA codes and standards.

e. The nature of the experimental work at the LLNL and Sandia/CA can produce unusual hazards, which require special treatment, training, and site 
knowledge. Emergency response services are best provided by an on-site fire department.

f. Because of the unique nature of their classified work, both LLNL and Sandia/CA desire to control the majority of emergencies utilizing personnel having the necessary security clearances.

g. LLNL, because of its large number of employees, their critical value to the LLNL mission, and the nature of its work, wishes to provide emergency medical service equal to or superior to that provided in the surrounding community.

h. Staffing and equipping a single fire department to control all potential worstcase scenarios is neither reasonable nor financially practical. Instead, LLNL desires an emergency response force that is organized and staffed to handle the most probable incident scenarios and relies on automatic and mutual aid to provide response to worst-case scenarios.

\section{Scope}

This document covers the following

- Response to fire emergencies

- Response to medical emergencies

- Response to hazardous materials emergencies

- Response to situations requiring technical rescue

- Monitoring of the site-wide emergency alarm system

- Emergency communications and dispatch requirements

- Pre-fire plan requirements

- Emergency response apparatus

Other fire protection program components (typically, those requiring fire protection engineering support) are not included in this assessment.

\section{Site Description}

\subsection{General Description ${ }^{2}$}

LLNL is a national resource in science and engineering, with a special responsibility for nuclear weapons. The Laboratory consists of two main facilities - the main laboratory site located in Livermore, California (Livermore Site), and the Experimental Test Facility (Site 300) located near Tracy, California. Laboratory activities are focused on national and global security, photon science, science and technology, nuclear stockpile stewardship, the environment, biomedicine, economic competitiveness, and science and mathematics education. The Laboratory's mission is dynamic and has been broadened over the years to meet new national needs. LLNL is a full-service research laboratory with the infrastructure, engineering, maintenance, and waste management activities, as well as security, fire, and medical departments-necessary to support its operations and personnel. 
LLNL's Livermore site occupies an area of approximately 813 acres, including the land that serves as a buffer zone around the site. Immediately to the south is Sandia National Laboratories, California (SNL/CA) which occupies approximately 413 acres. SNL/CA provides research and development associated with nuclear weapons systems engineering, as well as related national security tasks. Although their primary missions are similar, LLNL and SNL/CA are separate facilities, each with its own management and each reporting to a different DOE operations office. Site 300, LLNL's Experimental Test Site, is located 24 kilometers east of the Livermore site in the Altamont Hills of the Diablo Range; it occupies an area of 11.7 square miles (30.3 square kilometers). The primary work at Site 300 is explosive testing.

Beginning October 1, 2007 LLNL outsourced emergency response services to the Alameda County Fire Department (ACFD). As part of that outsourcing, all members of the LLNL Fire Department became employees of the ACFD and remained assigned to one of the two LLNL fire stations. Beginning January 1, 2008, ACFD took over operation of the LLNL Emergency Dispatch Center, which also served as the Alameda County Regional Emergency Communications Center (ACRECC). As part of that contract, ACRECC is responsible for the monitoring of the LLNL Fire and Emergency Voice Alarm (FEVA) system, answering emergency telephone calls, tracking emergency and non-emergency response resources, providing emergency pager notification for deaf or hearing impaired employees, and coordinating responses with LLNL and Sandia/CA protective forces.

The Emergency Management Department is the parent organization for fire protection, consisting of the Alarms Division, the Emergency Programs Division, and the Fire Protection Division. The Fire Protection Division is responsible for monitoring the contract with ACFD as well as for providing fire protection engineering and general fire protection and inspection services at LLNL.

Because of the proximity of Sandia National Laboratory-California (Sandia/CA), another DOE facility, the LLNL Fire Department provides Sandia with emergency dispatch and response services. This arrangement via a Memorandum of Understanding has been in place for over 30 years...

The Emergency Management Department organization is shown in Figure 4-1. For emergency response, ACFD provides three shifts each lead by a Battalion Chief. Each shift is divided into three companies. Two companies are assigned to the Livermore Site (ACFD Fire Station 20) and one company is assigned to Site 300 (ACFD Fire Station 21). Each shift is staffed at 13 to provide a Battalion Chief, three four-person companies. Minimum staffing is three four-person companies and a Battalion Chief.

Figure 4-1 Emergency Management Department Organization Chart 


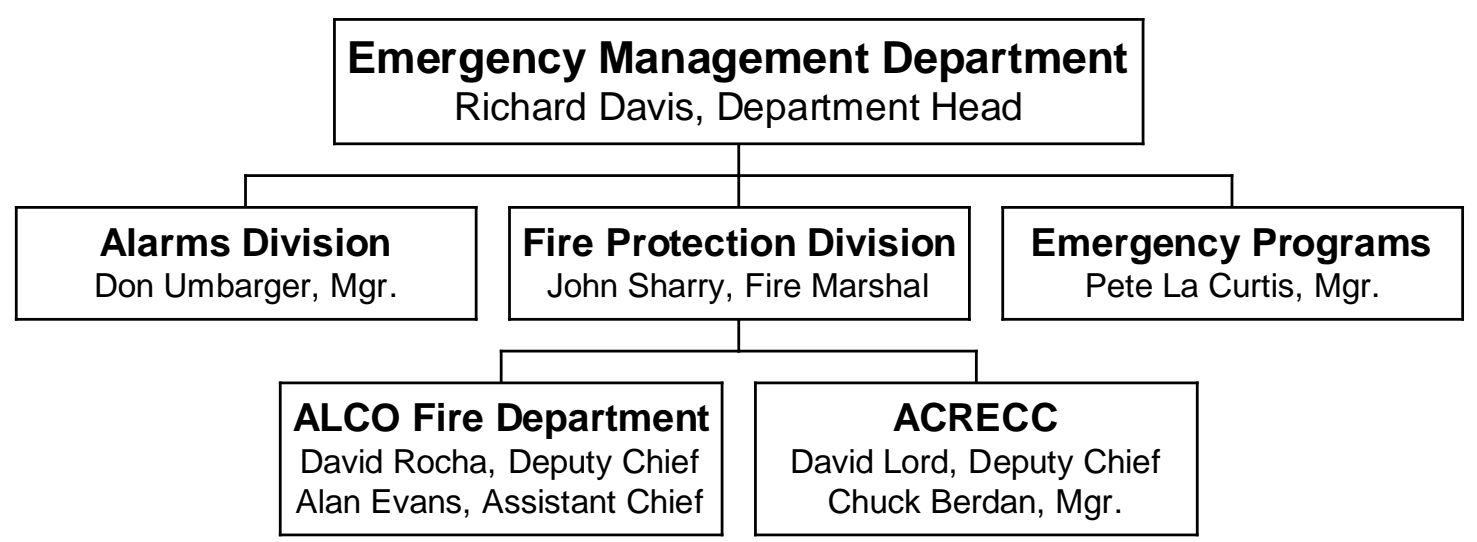

LLNL is signatory to several automatic aid and mutual aid agreement. LLNL meets its obligations to these agreements through its subcontractor, the Alameda County Fire Department. The agreements are as follows:

- Automatic Aid Agreement with the Livermore-Pleasanton Fire Department

- Automatic Aid Agreement with the Alameda County Fire Department

- Alameda County Mutual Aid Agreement

- Tracy Fire Department Mutual Aid Agreement

- Mutual Threat Zone MOU with California Division of Forestry

- Ambulance Response MOU with American Medical Response

- Mutual Fire Protection Resources Agreement with City of Livermore

\section{Requirement and Guidance Documents}

\subsection{Requirement Documents}

DOE Order (O) 420.1B, Facility Safety, requires that contractor sites have a comprehensive fire protection program that minimizes the potential for: an occurrence of a fire or related event; fires that cause unacceptable onsite or offsite release of hazardous or radiological material that could impact the health and safety of employees, the public, or the environment; unacceptable interruption of vital DOE programs; property loss from fire exceeding limits established by DOE; and fire damage to critical process controls and safety class systems structures and components. The order presumes access to a qualified and trained fire fighting staff. The Order requires the implementation of applicable NFPA codes and standards. ${ }^{3}$

DOE O 151.1C, Comprehensive Emergency Management System requires establishment and maintenance of plans and procedures for response to operational emergencies involving or affecting DOE facilities. The Order also requires that an organization be established and maintained for each site with overall responsibility for the initial and ongoing response to and mitigation of an emergency. ${ }^{4}$ In this analysis only the sections of Order dealing with emergency response and pre-planning, including Emergency Planning Hazards Assessments, are used. 
Title 10 Code of Federal Regulations Part 851, Department of Energy Worker Safety and Health Program, Appendix A.2 Fire Protection, requires that the DOE Contractor implement and maintain a comprehensive multi-faceted fire safety and emergency response program that is predicated, in part, on compliance with applicable building codes and National Fire Protection Association (NFPA) codes and standards and incorporate applicable provisions of DOE Order 420.1B. The rule specifically adopts NFPA 70 and NFPA 70E and generically references additional NFPA codes and standards that may be applicable. The rule specifically incorporates the following Occupational Safety and Health Administration (OSHA) standards for compliance at DOE sites:

Title 29 Code of Federal Regulations Part 1910.120, Hazardous Waste Operations and Emergency Response

Title 29 Code of Federal Regulations 1910.134 (g) (4), Procedure for Interior Structural Firefighting requires that anytime fire fighters are performing interior structural fire fighting in IDLH atmospheres, the fire fighting operations within the IDLH atmosphere shall operate in teams of at least two persons and that an additional team of two persons be available outside the IDLH atmosphere to provide emergency rescue.

Both the DOE O 420.1B and 10CFR851 require compliance with applicable NFPA codes and standards. These include as follows:

NFPA 13, Standard for the Installation of Automatic Sprinkler Systems, provides minimum criteria for the installation of automatic sprinkler systems including water supply requirements for sprinkler and hose line operation. For this analysis, only the sections of the standard pertaining to water supply for hose lines are used. ${ }^{5}$

NFPA 72, National Fire Alarm and Signaling Code, provides minimum criteria for installation of fire alarm systems and minimum requirements for operation of a proprietary supervising station. For this analysis only the portions of the standard dealing with operation of a proprietary supervising station alarm system are used. ${ }^{6}$

NFPA 472, Standard for Professional Competence of Responders to Hazardous Materials/Weapons of Mass Destruction Incidents, establishes training standards for personnel responding to hazardous materials incidents. ${ }^{7}$

NFPA 473, Standard for Competencies for EMS Personnel Responding to Hazardous Materials Incidents establishes training standards for EMS personnel responding to hazardous materials incidents. ${ }^{8}$

NFPA 1001, Standard for Fire Fighter Professional Qualifications establishes minimum job performance requirements for career fire fighters whose duties are primarily structural in nature. $^{9}$

NFPA 1002, Standard on Fire Apparatus Driver/Operator Professional Qualifications establishes minimum job performance requirements for fire fighters who drive and operate fire apparatus, in both emergency and nonemergency situations. ${ }^{10}$ 
NFPA 1006, Standard for Rescue Technician Professional Qualifications establishes the minimum job performance requirements necessary for emergency response personnel who perform technical rescue operations. ${ }^{11}$

NFPA 1021, Standard for Fire Officer Professional Qualifications establishes performance requirements necessary to perform the duties of a fire officer. ${ }^{12}$

NFPA 1051, Standard for Wildland Fire Fighter Professional Qualifications establishes the minimum job performance requirements for wildland fire duties and responsibilities. ${ }^{13}$

NFPA 1061, Standard for Professional Qualifications for Public Safety Telecommunicator establishes minimum job performance requirements for public safety telecommunicators, who are individuals whose primary responsibility is to receive, process, or disseminate information of a public safety nature via telecommunication devices. ${ }^{14}$

NFPA 1221, Standard for the Installation, maintenance, and Use of Emergency Services Communications Systems provides minimum provisions for reliable communications systems including provisions for the construction, maintenance, and operation of an emergency communications center. For this analysis, only the portions of the standard pertaining to operating procedures are used. ${ }^{15}$

NFPA 1404, Standard for Fire Service Respiratory Protection Training establishes minimum requirements for the training component of the respiratory protection program. ${ }^{16}$

NFPA 1403, Standard on Live Fire Training Evolutions establishes minimum requirements for training all fire suppression personnel engaged in fire-fighting operations under live fire conditions. ${ }^{17}$

NFPA 1500, Standard on Fire Department Occupational Safety and Health Program, establishes an occupational safety program that includes provisions for operating at an emergency. Among those provisions is the requirement commonly known as the Two-In/Two-Out Rule that requires a minimum of four fire fighters present and arranged in two teams of two before interior structure fire fighting can commence. ${ }^{18}$ In this analysis, only those sections of the standard dealing with staffing are used.

NFPA 1521, Standard for Fire Department Safety Officer establishes minimum requirements for the assignment, duties, and responsibilities of a health and safety officer (HSO) and an incident safety officer (ISO) for a fire department. In this analysis, only the sections pertaining to incident safety officer will be used to evaluate training for both fire department and LLNL incident safety officers. ${ }^{19}$

NFPA 1561, Standard on Emergency Services Incident Management System NFPA 1561 establishes minimum requirement for an incident management system to be used by emergency agencies in managing all emergency incidents. ${ }^{20}$

NFPA 1582, Standard on Comprehensive Medical Program for Fire Departments contains descriptive requirements for a comprehensive occupational medical program for fire departments including medical requirements for persons 
performing the job duties described in NFPA 1001, Standard for Fire Fighter Professional Qualifications; NFPA 1002, Standard for Fire Apparatus Driver/Operator Professional Qualifications; NFPA 1006, Standard for Rescue Technician Professional Qualifications; NFPA 1021, Standard for Fire Officer Professional Qualifications; and NFPA 1051, Standard for Wildland Fire Fighter Professional Qualifications. ${ }^{21}$

NFPA 1670, Standard on Operations and Training for Technical Rescue Incidents, establishes standards for operations and training for personnel responding to technical rescue incidents. ${ }^{22}$

NFPA 1710, Standard for the Organization and Deployment of Fire Suppression Operations, Emergency Medical Operations, and Special Operations to the Public by Career Fire Departments, establishes minimum response criteria for a variety of emergency events including structural fire fighting. ${ }^{23}$

NFPA 1901, Standard for Automotive Fire Apparatus provides minimum specifications for fire apparatus. ${ }^{24}$

NFPA 1906, Standard for Wildland Fire Apparatus provides minimum specifications for wildland fire apparatus. ${ }^{25}$

NFPA 1911, Standard for the Inspection, Maintenance, Testing, and Retirement of In-Service Automotive Fire Apparatus, provides minimum specifications for inspection, testing, and maintenance of fire apparatus. ${ }^{26}$

\subsection{Guidance Documents}

DOE G-420.1-3 Implementation Guide for DOE Fire Protection and Emergency Services Programs for Use with DOE O 420.1B, Facility Safety, provides detailed guidance information on key program elements including Fire Hazards Analysis and Baseline Needs Assessments. ${ }^{27}$

DOE G 440.0-8 Implementation guide for use with 10CFR851 Worker Safety and Health Program, provides detailed guidance information on key program elements for compliance with the Rule. ${ }^{28}$

DOE STD 1066-99, Fire Protection Design Criteria, provides supplementary guidance on fire protection criteria applicable for the design and construction of DOE facilities. ${ }^{29}$

DOD Instruction 6055.06, DoD Fire and Emergency Services (F\&ES) Program, is referenced in DOE G-420.1B as a source for analysis of emergency response needs in a Baseline Needs Assessment. ${ }^{30}$

NFPA 1620, Recommended Practice for Pre-Incident Planning provides recommendations on the preparations of pre-incident plans. ${ }^{31}$

\section{Primer on Terminology}

This assessment contains terminology and uses terms that are common in the emergency response community. This primer of fire department organization is provided 
to assist readers who may not be familiar with the organization and operations of a paramilitary emergency response organization such as a fire department.

\section{$\underline{\text { Apparatus }}$}

Fire department terminology is steeped in tradition. Vehicles are termed apparatus from the old days of horse drawn wagons. Similarly, tactical vehicles (apparatus) have historical names. For example, a vehicle that pumps water is often called a pumper but is usually referred to as an "engine" a reference to the original stream engine driven pumps of yester year. Originally, pumper apparatus provided one service, pumping water. Vehicle limitations prevented more than the single function. To get the water to the fire required hose that was carried on a separate vehicle called a hose wagon or wagon. As vehicle technology improved, hose was added to the same vehicle as the pump, later, the ability to carry storage tanks of water was also included. This resulted in a vehicle that provided three services, pump, hose, and water and was termed a triple combination pumper. However, the historic term engine is still used to describe this vehicle.

Similarly, a vehicle that carried ground ladders was termed a ladder truck. When technology evolved to produce the aerial ladder, the vehicle continued to be known as a ladder truck or more commonly simply referred to as a "truck."

\section{Companies}

Fire departments are typically organized into operational units called “companies.” A "company" consists of a leader (typically a Captain) and fire fighters who are assigned to an emergency response vehicle (apparatus) for the purposes of performing specific tasks at an incident. The type of apparatus to which the personnel are assigned dictates their basic task assignment. For example, an Engine is an emergency response vehicle that is equipped with a pump, hose and water. The apparatus and the personnel assigned become an Engine Company. An Engine Company's basic task assignment is fire attack using the pump, hose, water, and other equipment carried on their vehicle. Similarly, a Truck is an emergency response vehicle that carries ladders, an aerial ladder, and specialized tools and equipment. The apparatus and personnel assigned become a Truck Company. A Truck Company’s basic task assignment is search, rescue, ventilation, salvage, and overhaul.

\section{Equipment}

Equipment is what is carried on the apparatus. Equipment includes such things as couplings, adapters, salvage covers, hydraulic rescue tools, hand tools, etc.

\section{Fire Department}

A fire department is generally is defined as: a public, governmental, private, industrial, or military organization engaging in response providing rescue, fire suppression, and related services. $^{32}$ Most importantly, a fire department is an organization that responds to emergencies of unknown hazards, to enclosed structures with unknown layout and contents, and to transportation incidents involving unknown materials and hazards. The primary difference between a fire brigade and a fire department is that a fire brigade deals with a set of known problems and hazards that are limited to those that exist within the facility and that they are not expected to deal with the hazards and emergencies beyond the boundaries of the facility. Industrial organizations that 
respond to off-site emergencies that involve unfamiliar hazards are more properly defined as fire departments rather than fire brigades.

\section{Hose}

Hose is divided into two categories; supply hose and attack hose. In fire terminology, hose is often referred to as a "line" short for hose line. Supply hose is hose used to supply water from a source, for example - fire hydrant, to the fire apparatus at the scene. Attack hose or "attack lines" are the hose lines used by fire fighters or fire brigade members to apply water to the fire.

\section{Staffing and Safety Basics}

The company is the basic working unit of emergency operations. The number of personnel assigned to a company and basic safety practices dictate that a company can safely perform only one major task at a time. If the assignment of multiple simultaneous tasks results in the division of the company into single fire fighter task units, additional companies should be called. Any tactical task at an incident requires assignment of at least two persons. Assignment of a single fire fighter results in a fire fighter's attempting to perform task(s) that require multiple fire fighters, invariably resulting in injury. If an incident requires that multiple tasks be performed simultaneously resulting in assignment of single fire fighters to a task, sufficient additional companies must be assigned so that the task can be performed safely.

Because emergency response is an around-the-clock need, emergency response organizations must organize and staff for 24/7 response capability. Fire Departments on the west coast are typically organized and staffed based on 24hour shifts with personnel working an average 56-hour workweek. Each shift is supervised by a shift commander, often called a Battalion Chief.

\section{Determination on Minimum Response Requirements}

\section{DOE Fire Fighting Requirements}

The requirements of DOE Order 420.1B state that contractor sites must have a comprehensive fire protection program that minimizes the potential for an occurrence of:

- A fire or related event

- $\quad$ Fires that cause unacceptable onsite or offsite release of hazardous or radiological material that could impact the health and safety of employees, the public, or the environment;

- $\quad$ Unacceptable interruption of vital DOE programs;

- $\quad$ Property loss from fire exceeding limits established by DOE; and

- $\quad$ Fire damage to critical process controls and safety class systems structures and components.

DOE O 420.1B requires access to a qualified and trained fire fighting staff. ${ }^{33}$ Further guidance is contained in DOE G-420.1-3, which states that a baseline needs assessment is to establish the site fire fighting capabilities to provide effective response to suppress all fires and respond to emergency medical and hazardous materials incidents. ${ }^{34}$ 
This section will assess the capability of LLNL to meets these requirements using a set of performance metrics derived from NFPA standards and standards from other recognized organizations. The performance metrics derived in this section are based on the concept of being practical, reasonably achievable, economically viable, and providing equivalent performance.

\section{LLNL Situation Status}

LLNL has an emergency response force of two four-person engine companies at Site 200 (Livermore) and one four-person company at Site 300 staffed under contract by the Alameda County Fire Department. This initial response at Site 300 is backed-up by an automatic move-up response of one company from Site 200. An Alameda County Battalion Chief is dispatched on major incidents. Alameda County Fire Department can provide additional staffing from ACFD Station 8 on College Avenue in Livermore. Additional resources are also available from the Livermore Pleasanton Fire Department and by activation of the Alameda County Mutual Aid Plan.

\subsection{Structural Fire Fighting}

Minimum response requirements for structural firefighting can be broken into two major segments; initial attack and sustained attack. Initial attack is the actions taken by the first alarm units at a fire emergency. Sustained attack is actions taken by units beyond the first alarm assignment usually indicating the need for a large fire flow to contain or control the fire.

This assessment only addresses the ability to initiate an effective initial attack because the sustained attack will be supported through mutual aid responders and is not part of the baseline needs. There are three components to an initial attack:

- Fire flow required

- Staffing

- Response time

The timely arrival of initial attack units is of little benefit unless they can deliver an effective initial fire flow to the fire. Historically fire flow was used to determine minimum staffing, however, modern analysis of fire attack recognizes that fire attack is more than the ability to deploy a certain fire flow to the fire. Other tasks must also be accomplished in conjunction with application of the fire flow, however, the ability to deliver an effective fire flow is still a critical part of initial fire attack and is assessed below.

\subsubsection{Structural Fire Fighting - Site 200 (LLNL Livermore and SANDIA/CA)}

\subsubsection{Determining Structural Fire Flow}

NFPA 1710 performance metrics are based on a fire in an un-sprinklered residential occupancy, which requires the delivery of a 300 gallon per minute (GPM) fire flow using two attack lines, each flowing 150 gpm. As noted in the annex to NFPA 1710, fire flows for other occupancies and situations must be developed taking into account such factors as the adopted building codes, the type of construction, the hazards presented by the occupancy, and fire/life safety engineering controls. The determination of initial attack fire 
flow has been the subject of much debate, but there are several more or less standard means of making this determination. Usually the determination is broken into two general categories, sprinklered buildings and un-sprinklered buildings.

Sprinklered Buildings -- Based on the performance history of automatic sprinkler systems, the fact that a sprinklered room or space cannot proceed to flashover, and the expectation that the sprinkler system will at least control any fire, an initial attach fire flow of 300 gallons per minute (gpm) is proposed as being adequate. Using a variety of references, including NFPA $13^{35}$ the initial attack fire flow in buildings with automatic sprinklers can be justified at 150 gallons per minute (gpm).

NFPA 1710 bases its response times and staffing on the ability to arrive and provide an aggressive offensive fire attack prior to a phenomenon known as flashover. Flashover is that point in the development of a fire where there is a rapid transition in fire behavior from localized burning of fuel to involvement of all the combustibles in the enclosure. ${ }^{36}$ NFPA 1710 explains that, "two of the most important elements in limiting fire spread are the quick arrival of sufficient number of personnel and equipment to attack and extinguish the fire as close to the point of its origin as possible." 37

Research indicates that there are two triggering conditions for flashover: 1) a ceiling-gas-layer temperature of $1100^{\circ} \mathrm{F}$ and 2) a radiant flux on the unignited materials in the room of approximately $20 \mathrm{~kW} / \mathrm{m}^{2}$. Both of these conditions can be interrupted or prevented by the application of suppression agents. ${ }^{38}$ Therefore, it can be concluded that the operation of automatic sprinklers will prevent flashover. Because each automatic sprinkler head operates independently, with the closest sprinkler to the fire operating first, it can be expected that the goal of extinguishing or controlling the fire as close to the point of origin as possible will be accomplished. In summary, an automatic sprinkler system can be expected to prevent development of flashover conditions during a fire and meet the goals of NFPA 1710 of extinguishing the fire as close to the point of origin as possible.

The history of automatic sprinkler protection is well documented within the DOE and the fire protection community as a whole. DOE statistics indicate that $99 \%$ of all fires will be contained by the operation of the sprinkler system. ${ }^{39}$ Factory Mutual Research Corp. reports that in a study of 2,860 fires in industrial buildings, $92 \%$ of all fires will be contained by the operation of 20 or fewer sprinklers. ${ }^{40}$ A 2007 study of fires in sprinklered occupancies in calendar years 2002-2004 by the National Fire Protection Association estimates that sprinklers are effective in $97 \%$ of the fires large enough to cause sprinkler activation. Sprinklers were reported to be effective (flashover prevented) $90 \%$ of the time overall when considering all fires, including those deemed too small to activate the sprinkler system. ${ }^{41}$ From the research, it can be concluded that in sprinklered buildings, where the sprinkler systems prevent flashover and control the fire, it will not be necessary to mount a full initial fire attack, but rather to provide a single hose line to "mop-up" any remaining fire. Based on this information the minimum required fire flow for sprinklered buildings is determined to be $150 \mathrm{gpm}$, the fire flow from a standard fire department attack line.

Data provided by LLNL facility management shows that $90 \%$ of the total building area and $100 \%$ of significant buildings at LLNL are provided with automatic sprinkler protection. Sandia/CA has $99 \%$ of building areas protected by automatic sprinklers. 
Un-Sprinklered Buildings -LLNL - While 90\% of the total building area at LLNL is provided with automatic sprinkler protection; however, this accounts for only about $65 \%$ of the number of structures. Many small and moderate sized buildings are not protected with any form of automatic suppression. Fire flows for a sample of unsprinklered buildings of various sizes were calculated using methods contained the Society of Fire Protection Engineers Technical Publication TP2007/1. ${ }^{42}$ These calculations indicated fire flow requirements ranging from 300 to 2,250 gpm. For purposes of determining minimum requirements for manual fire fighting in an industrial occupancy during initial attack, a fire flow of 300 gpm was selected which is consistent with NFPA 1710, which assumes a $300 \mathrm{gpm}$ fire flow for a residential structure. ${ }^{43}$ Fire flows exceeding $300 \mathrm{gpm}$ are considered sustained fire attack that will involve multiple alarms or extensive use of mutual aid and are beyond the scope of initial fire attack. The higher values provided by the various methods to determine flow are theoretical maximums for purposes of design of water supply piping which must supply water during a sustained attack as well as an initial attack. The 300 gpm initial attack fire flow represents a bounding worst case for the water demand during an initial attack.

Un-Sprinklered Buildings -Sandia/CA - 99\% of the total building area at Sandia/CA is sprinklered. The buildings that are not sprinklered are small in floor area ( $<1,600$ sq. ft.), remotely located, or incompatible with water application.

\subsubsection{Delivering Structural Fire Flow}

From the determined fire flow, partial staffing can be derived by determining hose line size and minimum staffing for each hose line. If a higher fire flow is necessary, either larger hose lines or more hose lines must be deployed. The following table describes hose line delivery capacity and minimum staffing as determined via a number of sources.

Table 7.1.2.2 Hose Line Staffing

\begin{tabular}{|c|c|c|}
\hline $\begin{array}{l}\text { Attack Line } \\
\text { Diameter }\end{array}$ & $\begin{array}{c}\text { Water Delivery } \\
\text { in G.P.M. }\end{array}$ & $\begin{array}{c}\text { Minimum } \\
\text { Staffing** }\end{array}$ \\
\hline $1-1 / 2$ in. & 150 & 2 \\
\hline $1-3 / 4$ in. & 190 & 2 \\
\hline $2-1 / 2$ in. & 250 & 3 \\
\hline
\end{tabular}

** Staffing for hose line only. Does not include rescue team if operating in IDLH atmosphere.

Using this table, the staffing for the hose line portion of the initial fire attack can be determined. For a required flow of $150 \mathrm{gpm}$, a minimum hose line staffing of two is required. For a $300 \mathrm{gpm}$ fire flow a minimum hose line staffing of four (two 1-1/2 in. lines) would be needed. A sustained fire attack would require additional personnel.

\subsubsection{Minimum Requirements - Structural Fire Fighting}

The Critical Task Method was developed by the Center for Public Safety Excellence (formerly the National Fire Service Accreditation Task Force and Commission on Fire Service Accreditation). ${ }^{44}$ This method considers staffing for certain "critical tasks" which are deemed necessary for an initial fire attack. Staffing for Search and Rescue, Ventilation, Back-up Lines, Safety Crews, Pump Operators, Water Supply, and Incident 
Command are considered in addition to that required for hose line operation. The method assumes that these tasks must be performed simultaneously in order to have an effective fire attack. The following table summarizes the staffing necessary for the bounding worse case fire flow, a 300-gpm initial fire attack, using this method:

Table 7.1.1.3 Critical Task Method Staffing Level

\begin{tabular}{|l|c|l|}
\hline \multicolumn{1}{|c|}{ Task } & Staffing & \multicolumn{1}{c|}{ Comments } \\
\hline $1^{\text {st }} 150$ gpm. hose line & 4 & 2-In/2-Out \\
\hline $2^{\text {nd }} 150$ gpm. hose line & 2 & 3-In, 2-Out shared with first line \\
\hline Search and Rescue & 2 & 2-person crew \\
\hline Ventilation & 2 & 2-person crew \\
\hline Pump Operations & 2 & Pump operator and hose support \\
\hline Incident Command & 1 & Chief Officer \\
\hline TOTAL & 13 & \\
\hline
\end{tabular}

\subsubsection{Response Standards Method}

The Response Standards Method is based on the critical task method but broadened to include additional personnel. It is the method contained in NFPA $1710 .^{45}$

The basic provisions of NFPA 1710 with regard to staffing are as follows:

- Establishment of a dedicated Incident Command

- Establishment of effective fire attack from two hose lines

- Establishment of Initial Response Intervention Crew(IRIC) ${ }^{1}$ of 2 persons

- Fire attack hose lines staffed by at least 2 persons each

- Establishment of uninterrupted water supply of $400 \mathrm{gpm}$ for 30 minutes maintained by an operator

- Establishment of at least one search and rescue team consisting of 2 persons

- Establishment of a ventilation team consisting of 2 persons

- Provision of at least one support person for each attack and back-up line below:

The staffing for these requirements adjusted for 300 -gpm fire flow is summarized

Table 7.1.1.4 NFPA 1710 Staffing Level

\begin{tabular}{|l|c|l|}
\hline \multicolumn{1}{|c|}{ Task } & Staffing & \multicolumn{1}{c|}{ Comments } \\
\hline Incident Command & 1 & Battalion Chief \\
\hline Deploy two hose lines & 4 & 2-In for each hose line \\
\hline Search \& Rescue & 2 & 2-Person crew \\
\hline Ventilation & 2 & 2-Person crew \\
\hline IRIC & 2 & 2-Person crew \\
\hline Water Supply & 1 & Pump Operator \\
\hline Support & 2 & 1 for each hose line in service \\
\hline \multicolumn{1}{|c|}{ TOTAL } & 14 & \\
\hline
\end{tabular}

\footnotetext{
${ }^{1}$ Initial Rapid Intervention Crew or IRIC consists of two members of the initial attack crew who are assigned for rapid deployment to rescue lost or trapped members.
} 


\subsubsection{Analysis - Staffing}

Both the Critical Task Method and the Response Standards Method treat all buildings equally making no allowance for buildings with built-in fire protection. Annex note A.5.2.3.2.1 to NFPA 1710 states that the provisions of the standard are based on response to a structural fire in a 2,000 sq ft, two-story, single-family dwelling, with no basement or exposures and that other occupancies and structures that present greater hazards should be addressed. ${ }^{46}$ Presumably, occupancies in structures that present lesser hazards can also be addressed. In support of that presumption, it is noted that NFPA 1710 contains an equivalency statement that permits "the use of systems, methods, or approaches of equivalent or superior performance." 47

As indicated above it can be concluded that in sprinklered buildings, where the sprinkler systems prevent flashover and control the fire, a single 150-gpm hose line to "mop-up" any remaining fire is adequate. Although 90\% of all LLNL building area is sprinklered, the minimum staffing will be based on a 300-gpm fire attack, the bounding case. It is generally accepted that the Ventilation task can be delayed or eliminated in sprinklered buildings and that the Search and Rescue task can be delayed for occupancies present on the LLNL and Sandia campuses where building occupants are normally alert and awake. The Search and Rescue function is very important in sleeping occupancies, the occupancy on which 1710 was based. The LLNL and Sandia campuses do not contain sleeping occupancies, the exception being the fire stations. If confronted with a rescue situation, the first arriving company can perform that function and delay fire attack.

In practice, the allocation of one support person for each hose line in service is found to be excessive. One support person for all hose lines in initial attack is adequate.

Based on the above analysis, and the fact that buildings protected by automatic sprinklers systems provide a superior level of protection than contemplated by the NFPA 1710; the staffing for initial fire response can be set at as follows:

Table 7.1.1.5-1 Staffing for Fire Attack Facilities

\begin{tabular}{|l|c|l|}
\hline \multicolumn{1}{|c|}{ Task } & Staffing & \multicolumn{1}{c|}{ Comments } \\
\hline Incident Command & 1 & Battalion Chief \\
\hline Deploy two hose lines & 4 & 2-In for each hose line \\
\hline Search \& Rescue & - & Can be delayed \\
\hline Ventilation & - & 2-Person crew \\
\hline IRIC & 2 & 2-Person crew \\
\hline Water Supply & 1 & Pump Operator \\
\hline Support & 1 & 1 for each hose line in service \\
\hline \multicolumn{1}{|c|}{ TOTAL } & 9 & \\
\hline
\end{tabular}

DOE's Fire Safety Program Implementation Guide suggests that fire departments should respond with emergency medical capabilities. Typically, this is the response of an ambulance with the fire attack crews. In many instances, emergency medical services can be provided by one of the fire crews (Engine Company) with transport being provided by mutual aid resources. NFPA 1710 is silent on this topic, but NFPA 1500 provides that the Incident Commander shall assess the risk to personnel and determine if on-scene medical 
support and transportation is necessary. ${ }^{48}$ Companies staffed and equipped to provide emergency medical service are considered a satisfactory means of meeting this concern.

Although not directly related to fire protection, the Emergency Preparedness Hazards Assessments produced as part of LLNL's implementation of DOE 151.1 require prompt response from trained emergency responders to mitigate the potential threat to the public from incidents involving hazardous materials. The on-site fire department provides this service. DOE 151.1 does not provide specific staffing criteria or response times and, therefore, was not used to develop minimum response criteria.

\subsubsection{Analysis - Response Time}

To truly measure response time to an emergency it is logical to evaluate the entire time sequence from initial contact of the reporting party until arrival at scene which includes dispatch processing time, turn-out time and travel time. Dispatch processing time, sometimes called dispatch hold time, is the time from initial contact until dispatch of companies. Turnout time, sometimes called reflex time, and is the time from dispatch until travel to the emergency begins. The summation of dispatch hold time, reflex time, and travel time is often called Total Response Time.

Because Total Response Time is a more comprehensive metric than just travel time, this analysis will use total response time for all evaluations. The following table shows the response time metric and its components of dispatch hold time, turnout time and travel time as specified in NFPA 1710 and 1221.

Table 7.1.1.6 Total Response Times

\begin{tabular}{|l|c|c|c|c|}
\hline \multicolumn{1}{|c|}{ Service } & $\begin{array}{c}\text { Dispatch } \\
\text { Hold } \\
\text { Time } \\
\text { (seconds) }\end{array}$ & $\begin{array}{c}\text { Turn-Out } \\
\text { Time } \\
\text { (seconds) }\end{array}$ & $\begin{array}{c}\text { Travel } \\
\text { Time } \\
\text { (seconds) }\end{array}$ & $\begin{array}{c}\text { Response Time } \\
\text { (seconds) }\end{array}$ \\
\hline $\begin{array}{l}\text { Structure Fire } \\
1^{\text {st }} \text { Arriving Fire Unit }\end{array}$ & 60 & 80 & 240 & 380 \\
\hline $\begin{array}{l}\text { Structure Fire } \\
\text { Remainder of } 1^{\text {st }} \text { Alarm }\end{array}$ & 60 & 80 & 480 & 620 \\
\hline
\end{tabular}

\subsubsection{Minimum Performance Measure - Structural Fire Fighting Site 200 (LLNL Livermore \&Sandia/CA)}

The level of emergency response is based on the potential hazard presented. Based on the provisions of NFPA 1710 and the above rationale regarding the level of protection provided, the following minimum performance measure is derived:

Respond to alarms in buildings with an initial alarm assignment of one engine company (minimum staff of 4) to provide for arrival within 380 seconds Total Response Time $90 \%$ of the time and provide for the arrival of the rest of the alarm assignment within a Total Response Time of 620 seconds $90 \%$ of the time. 


\subsubsection{Requirements Summary - Structural Fire Fighting - Site 200 (LLNL Livermore and Sandia/CA)}

Table 7.1.1.8 Performance Summary - Structural Fire Fighting Site 200 (LLNL Livermore \&SANDIA/CA)

\begin{tabular}{|l|c|c|c|c|}
\hline Type Incident & Responders & $\begin{array}{c}\text { Minimum } \\
\text { Staffing } \\
\text { (persons) }\end{array}$ & $\begin{array}{c}\text { Total } \\
\text { Response } \\
\text { Time }\end{array}$ & $\begin{array}{c}\text { Performance } \\
\text { Criteria }\end{array}$ \\
\hline \multirow{2}{*}{ Structure Fire } & $1^{\text {st }}$ Unit & 4 & 380 & $90 \%$ \\
\cline { 2 - 5 } & Remainder of $1^{\text {st }}$ Alarm & 5 & 620 & $90 \%$ \\
\hline
\end{tabular}

\subsubsection{Structural Fire Fighting - Site $\mathbf{3 0 0}$}

\subsubsection{Minimum Requirements - Structural Fire Fighting - Site $\mathbf{3 0 0}$}

The minimum response requirements for structural fires at Site 300 are the same as that derived for the Livermore Site. However, the nature of operations at Site 300 (high explosive formulation and testing) dictates that buildings outside of the general service area be widely spaced, generally require a high explosive (HE) setback, and require a cooling off period, delaying building entry for a minimum of 30 minutes. Because of these factors, a response time for those buildings outside of the general service area can be extended as a matter of necessity and reason. This delay is in keeping with NFPA 1710 which states that there can be areas where the response criteria are impacted by circumstances such as natural barriers, insufficient water supply, or low density of population or property. ${ }^{49} \mathrm{~A}$ Total Response Time of 960 seconds $90 \%$ of the time has been selected as a reasonable response time for those buildings outside of the General Service Area.

The response schedule for Site 300 calls for the automatic dispatch of an engine company from the Livermore Site on any fire response at Site 300; however, because of the remote location and travel distance to Site 300, travel time will be 15 to 30 minutes. Because there is no fire department responsible for the area surrounding Site 300 (the California Division of Forestry and Fire Protection is responsible for fire response to this area during wildland fire season, nominally June through October, and is not available to assist during the rest of the year) there is no fire department with a better response time. In keeping with NFPA 1710's provisions for such situations, a Total Response Time for the second engine has been set at 1800 seconds. The same criterion is used for the arrival of a Battalion Chief.

\subsubsection{Minimum Performance Measure - Structural Fire Fighting - Site $\mathbf{3 0 0}$}

Based on the provisions of NFPA 1710 and the above rationale, the following minimum performance measures are derived:

GSA Buildings

Respond to alarms in buildings with sprinkler protection within the General Services Area of Site 300 with a alarm assignment of one engine company (minimum staff of 4) to provide for arrival within a Total Response Time of 380 
seconds $90 \%$ of the time and provide for the arrival of the remainder of the first alarm within a Total Response Time of 1800 seconds $90 \%$ of the time.

Outside of GSA Buildings

Respond to fire incidents outside of the general services area with an alarm assignment of one engine company to provide for arrival within a Total Response Time of 960 seconds $90 \%$ of the time and provide for the arrival of the remainder of the first alarm assignment within a Total Response Time of 2760 seconds $90 \%$ of the time.

\subsubsection{Requirements Summary - Structural Fire Fighting - Site $\mathbf{3 0 0}$}

Table 7.1.2.3 Performance Summary - Structural Fire Fighting S-300

\begin{tabular}{|l|l|c|c|c|}
\hline \multirow{2}{*}{ Type Incident } & \multicolumn{1}{|c|}{ Responders } & $\begin{array}{c}\text { Minimum } \\
\text { Staffing } \\
\text { (persons) }\end{array}$ & $\begin{array}{c}\text { Total } \\
\text { Response } \\
\text { Time }\end{array}$ & $\begin{array}{c}\text { Performance } \\
\text { Criteria }\end{array}$ \\
\hline GSA Area & $1^{\text {st }}$ Unit & 4 & $380 \mathrm{sec}$. & $90 \%$ \\
\cline { 2 - 5 } Structure Fire & Remainder of $1^{\text {st }}$ Alarm & 5 & $1800 \mathrm{sec}$. & $90 \%$ \\
\hline $\begin{array}{l}\text { Non GSA Area } \\
\text { Structure Fire }\end{array}$ & $1^{\text {st } \text { Unit }}$ & 4 & $960 \mathrm{sec}$. & $90 \%$ \\
\cline { 2 - 5 } & Remainder of $1^{\text {st }}$ Alarm & 5 & 2760 sec. & $90 \%$ \\
\hline
\end{tabular}

\subsection{Wildland Fire Fighting}

\subsubsection{Wildland Fire Fighting - Site 200 (LLNL Livermore \& Sandia/CA)}

\subsubsection{Minimum Requirements - Wildland Fire Fighting - Site 200 (LLNL Livermore \&SANDIA/CA)}

LLNL S-200 has a small wildland fire threat mostly concentrated on the West and North sides in the buffer zone. Sandia/CA has a more significant wildland fire threat on three sides: East, West, and South. Vegetation at on both LLNL and Sandia/CA consists mostly of perennial grasses. This vegetation creates a fuel during the summer months that is generally light and flashy resulting in fast moving fires that pose little threat to permanent buildings with adequate clear space around them.

Both LLNL and Sandia/CA impose measures mitigate the wildland fire threat. Both sites restrict fuels within $20 \mathrm{ft}$. of permanent buildings. LLNL limits fuel by mowing the buffer zones to a height of less than 6 inches, a height that will not sustain a fast moving fire. Sandia/CA cuts fire breaks compliant with Alameda County Fire Code rural weed abatement requirements

The standard fire attack for a grassland fire is a two-flank attack utilizing off-road wildland fire fighting vehicles. This provides a fast initial attack for fire containment. Each wildland vehicle must be staffed with two personnel (one driver and one person to attack the fire) and be capable of pumping one hose line providing 20 gpm while moving.

NFPA 1710 recognizes special deployment provisions for wildland fires that can be summarized as follows: ${ }^{50}$ 
o Staffing operations shall be the number necessary for safe and effective fire fighting performance.

o Personnel assigned to wildland operations shall have appropriate apparatus.

- Wildland companies shall be staffed as required by the tactical, topographical, environmental, fuel (vegetation), and occupancy hazards.

o Safely initiate a direct attack within 10 minutes after arrival at fire scene.

0 No specific response time is specified for wildland fire responses.

\subsubsection{Analysis - Wildland Fire Fighting - Site 200 (LLNL Livermore and Sandia/CA)}

NFPA 1710 does not specify response times for wildland fires, however, it is reasonable to apply the structure fire response times, modified appropriately. Fire companies in California are well versed in wildland fire attack and arrive at the fire scene ready to initiate fire attack. The 10 minute time factor to initiate fire attack contained in NFPA 1710 is not realistic for companies located in wildland fire areas. In recognition of these facts, the NFPA 1710 time to fire attack is reduced to 1 minute. Time for direct attack will be determined by adding 1 minute to the Total Response Time.

The following table shows the response time metric and its components of dispatch hold time, turnout time and travel time as specified in NFPA 1710 and 1221. Response time for wildland fires will include the added minute to prepare for fire attack.

Table 7.2.1.2 Total Response Times - Wildland Fires Site 200

\begin{tabular}{|l|c|c|c|c|}
\hline \multicolumn{1}{|c|}{ Service } & $\begin{array}{c}\text { Dispatch } \\
\text { Hold } \\
\text { Time } \\
\text { (seconds) }\end{array}$ & $\begin{array}{c}\text { Turn-Out } \\
\text { Time } \\
\text { (seconds) }\end{array}$ & $\begin{array}{c}\text { Travel } \\
\text { Time } \\
\text { (seconds) }\end{array}$ & $\begin{array}{c}\text { Response Time } \\
\text { (seconds) }\end{array}$ \\
\hline $\begin{array}{l}\text { Wildland Fire } \\
1^{\text {st }} \text { Arriving Fire Units }\end{array}$ & 60 & 80 & 300 & 440 \\
\hline $\begin{array}{l}\text { Wildland Fire } \\
\text { Remainder of } 1^{\text {st }} \text { Alarm }\end{array}$ & 60 & 80 & 480 & 620 \\
\hline
\end{tabular}

\subsubsection{Minimum Performance Measure - Wildland Fire Fighting - Site 200 (LLNL Livermore and Sandia/CA)}

Based on the provisions of NFPA 1710 and the above rationale the following minimum performance measure is derived:

\section{Wildland Fire}

Respond to a reported wildland fire within a Total Response Time for a two-flank wildland fire attack of 440 seconds $90 \%$ of the time and provide for the arrival of a Battalion Chief within a Total Response Time of 620 seconds $90 \%$ of the time. 


\subsubsection{Requirements Summary - Wildland Fire Fighting - Site 200 (LLNL Livermore and Sandia/CA)}

Table 7.2.4 Requirements Summary - Wildland Fire Fighting Site 200 (LLNL Livermore \&SANDIA/CA)

\begin{tabular}{|c|c|c|c|c|}
\hline Type Incident & Responders & $\begin{array}{c}\text { Minimum } \\
\text { Staffing } \\
\text { (persons) }\end{array}$ & $\begin{array}{c}\text { Total } \\
\text { Response } \\
\text { Time }\end{array}$ & $\begin{array}{c}\text { Performance } \\
\text { Criteria }\end{array}$ \\
\hline \multirow{2}{*}{ Wildland Fire } & $1^{\text {st }}$ Units & 4 & 440 & $90 \%$ \\
\cline { 2 - 5 } & Remainder of $1^{\text {st }}$ Alarm & 1 & 620 & $90 \%$ \\
\hline
\end{tabular}

\subsubsection{Wildland Fire Fighting - Site $\mathbf{3 0 0}$}

\subsubsection{Minimum Requirements - Wildland Fire Fighting - Site $\mathbf{3 0 0}$}

Site 300 has a significant wildland fire threat. That threat requires additional evaluation for minimum response requirements. (In 1984 a large wildland fire originated in the HE burn pit adjacent to B827 at Site 300. The fire eventually spread off site and consumed several thousand acres both on and off Site 300 property, but did not cause damage to any building.)

To mitigate the wildland fire threat, Site 300 imposes measures to restrict fuels within $20 \mathrm{ft}$. of permanent buildings and conducts a prescribed burn of specific areas. The prescribed burn, conducted in the spring of each year, is designed to contain any fires originating within Site 300 to within Site 300 and to create a barrier to prevent fires originating off Site 300 property from burning onto Site 300.

The wildland attack and NFPA 1710 comments mentioned for LLNL Site 200 apply at Site 300 as well. Total response time for wildland fires will be the same as structural fires outside of the GSA area, plus the one-minute preparation for fire attack.

Based on the provisions of NFPA 1710 and the above rationale, the following minimum performance measures are derived:

Wildland Fires

Respond to a reported wildland fire at Site 300 within a Total Response Time for a two-flank wildland fire attack of 1020 seconds $90 \%$ of the time and provide for the arrival of the remainder of the first alarm within a Total Response Time of 2760 seconds $90 \%$ of the time.

\subsubsection{Requirements Summary - Wildland Fires - Site $\mathbf{3 0 0}$}

Table 7.2.2.2 Requirements Summary - Wildland Fire - Site 300

\begin{tabular}{|c|c|c|c|c|}
\hline Type Incident & Responders & $\begin{array}{c}\text { Minimum } \\
\text { Staffing } \\
\text { (persons) }\end{array}$ & $\begin{array}{c}\text { Total } \\
\text { Response } \\
\text { Time }\end{array}$ & $\begin{array}{c}\text { Performance } \\
\text { Criteria }\end{array}$ \\
\hline \multirow{2}{*}{ Wildland Fire } & $1^{\text {st }}$ Units & 4 & 1020 sec. & $90 \%$ \\
\cline { 2 - 5 } & Remainder of $1^{\text {st }}$ Alarm & 5 & 2760 sec. & $90 \%$ \\
\hline
\end{tabular}




\subsection{Emergency Medical Service (EMS) Requirements}

\subsubsection{Determination of Minimum Response Requirements - EMS}

The NFPA 1710 response standards for emergency medical service (EMS) are dependent upon the service level authorized by the local health authority. The standard contemplates a minimum response of basic life support (BLS) first responder trained personnel with automatic external defibrillator (AED) capability for arrival on scene within a Total Response Time of 300 seconds. If advanced life support is provided, response standards require the arrival of advanced life support (ALS) personnel within a Total Response Time of 600 seconds assuming a BLS with AED first response within 300 seconds. ${ }^{51}$

Aside from NFPA 1710, there are no national standards for emergency medical response. The Department of Transportation has driven the emergency medical training requirements for many years under the guise of requiring state to adopt certain minimum standards to receive federal highway funds. The DOT requirements do not include response time standards. However, the Alameda County Emergency Medical Services Agency has established response times in their Ambulance Provider Agreement. The Total Response Time under this contract for first responder ALS units in the Metro/Urban Area (those areas, such as LLNL, with a population density of between 101 and 500 persons per square mile) is 480 seconds. This local EMS Agency standard will be the Total Response Time used for LLNL and Sandia/CA responses. In Suburban/Rural Areas (those areas with a population density of between 7 and 100 persons per square mile, such as that around Site 300), the EMS agency establishes an ambulance Total Response Time criteria of 900 seconds $90 \%$ of the time.

Both NFPA 1710 and typical EMS standards establish a minimum staffing of two ALS qualified personnel for an ALS transport. NFPA 1710 presumes that there will also be two BLS qualified personnel on scene. One ALS and two BLS qualified personnel will be used as the staffing standard for LLNL with the assumption that if a true ALS transport is necessary a second ALS qualified fire fighter can be obtained from an additional company.

DOE's Fire Safety Program Implementation Guide suggests that fire departments should respond with emergency medical capabilities. Typically, this is the response of an ambulance with the fire attack crews. NFPA 1710 is silent on this topic, but NFPA 1500 provides that the Incident Commander shall assess the risk to personnel and determine if on-scene medical support and transportation is necessary. ${ }^{52}$ EMS needs at a fire event can be handled by one of the responding engine companies. Fire companies assigned to LLNL and their mutual aid and automatic aid partners provide ALS first responder engine companies that carry all ALS medical equipment and supplies. If EMS needs arise during a fire event, one company can be assigned to EMS while other companies continue firefighting efforts. Transport capabilities under these circumstances can be provided via outside agency ambulance. 


\subsubsection{Minimum Requirements - EMS}

Based on the requirements of NFPA 1710 and the Alameda County EMS Agency, the minimum performance measure is established as follows:

Site 200, Sandia/CA, GSA Area of S-300

Arrive on scene of an EMS incident on the at Site 200, Sandia/CA, or the GSA

Area of S-300 with first responder/transport ALS capability of one ALS and two

$B L S$ qualified responders within a response time of 480 seconds $90 \%$ of the time.

Outside of GSA Area of S-300

Arrive on the scene of an EMS incident Outside of the GSA Area of Site 300 with first responder/transport ALS capability of one ALS and two BLS qualified responders within a Total Response Time of 900 seconds $90 \%$ of the time.

\subsubsection{Requirements Summary -- EMS}

Table 7.3.3 Requirements Summary -- EMS

\begin{tabular}{|c|c|c|c|}
\hline Type Incident & Responders & $\begin{array}{c}\text { Minimum } \\
\text { Staffing } \\
\text { (persons) }\end{array}$ & $\begin{array}{c}\text { Response } \\
\text { Time }\end{array}$ \\
\hline $\begin{array}{c}\text { All EMS } \\
\text { Except Site 300 Non GSA }\end{array}$ & $1^{\text {st }}$ Responder/Transport & $\begin{array}{l}1 \text { ALS } \\
2 \text { BLS }\end{array}$ & 480 sec. \\
\hline $\begin{array}{c}\text { EMS } \\
\text { Site 300 Non GSA }\end{array}$ & $1^{\text {st }}$ Responder/Transport & $\begin{array}{l}1 \text { ALS } \\
2 \text { BLS }\end{array}$ & 900 sec. \\
\hline
\end{tabular}

\subsection{Hazardous Materials (HAZMAT) Response Requirements}

\subsubsection{Determination of Minimum Response Requirements - HAZMAT}

Both Sandia and LLNL perform experimental work using hazardous materials of various types, in a secure environment. The materials range from normal research chemicals to exotic one-of-a-kind compounds and can include radioactive materials of various types, forms, and quantities. It is important that there be a hazardous materials response capability that can have immediate access to classified areas and can maintain the classified nature of the work being performed.

NFPA 1710 does not establish specific response or staffing requirements for response to hazardous materials incidents. It simply states that the fire department shall ensure that the fire department's hazardous materials response capability includes personnel, equipment, and resources to deploy at the first responder operational level as required by 29 CFR $1910.120 .^{53}$ DOE 420.1B states that the emergency response organization (assumed to be the fire department) establishes capabilities to respond to hazardous materials incidents.

NFPA 472, Standard for Professional Competence of Responders to Hazardous Materials/Weapons of Mass Destruction Incidents sets standards for competencies for those responding to hazardous materials operations by categorizing those responders into one of four categories: 
- Awareness Level. Awareness level personnel are those persons who, in the course of their normal duties, can be the first on the scene of an emergency involving hazardous materials. Awareness level personnel are expected to recognize the presence of hazardous materials/WMD, protect themselves, call for trained personnel, and secure the area.

- Operations Level. Operations level responders are those persons who respond to hazardous materials/WMD incidents for the purpose of protecting nearby persons, the environment, or property from the effects of the release. They should be trained to respond in a defensive fashion to control the release from a safe distance and keep it from spreading. Operations level responders can have additional competencies that are specific to their response mission, expected tasks, and equipment and training as determined by the AHJ.

- Technician Level. Hazardous materials technicians are those persons who respond to releases or potential releases of hazardous materials for the purpose of controlling the release. Hazardous materials technicians are expected to use specialized chemical protective clothing and specialized control equipment. Hazardous materials technicians respond to hazardous materials/WMD incidents using a risk-based response process with the ability to analyze a problem involving hazardous materials/WMD, select appropriate decontamination procedures, and control a release using specialized protective clothing and control equipment. Hazardous materials technicians can have additional competencies that are specific to their response mission, expected tasks, and equipment and training as determined by the AHJ.

- Command Level. The incident commander is that person who is responsible for all decisions relating to the management of the incident. The incident commander is in charge of the incident site. ${ }^{54}$

Depending upon the level of response, the training, and competencies contained in NFPA 472 must be followed. While no specific mandatory staffing is defined by any of the referenced documents, it is clear that certain functions and actions outlined in OSHA 1910.120 and NFPA 472 and 473 must be taken at the scene of a hazardous materials event, from which minimum staffing can be derived.

The response time criteria established by NFPA 1710 for structural fires and the staffing requirements of EMD Policy 1612 will be the basis for the response requirements. Training requirements, although mentioned here, will be evaluated in the Training and Certification Section.

Based on the provisions of the requirements documents, response to hazardous materials incidents can be classified into three levels. Investigation Level incidents are those incidents in which no operational actions must be taken, but the material can be isolated until arrangement for clean up. These incidents require personnel trained to the Awareness Level per NFPA $472^{55}$. The minimum response staffing is determined to be four (Incident Commander and three personnel with a minimum of Awareness Training).

Level One incidents are those incidents in which minimal operational actions must be taken to stabilize the situation and make the scene safe until clean up. Level One incidents can be handled with persons trained to the Technician Level (NFPA $472^{56}$ and California Hazardous Materials Technician Certification). Minimum staffing is as follows: 
Table 7.4.1-1 Level One HAZMAT Staffing

\begin{tabular}{|c|c|c|}
\hline Task & Staffing & Minimum Training Level \\
\hline Incident Commander & 1 & Command \\
\hline Hazmat Group Supervisor & 1 & Technician \\
\hline Hazmat Safety & 1 & HM Safety Officer \\
\hline Technical Reference & 1 & Technician \\
\hline Entry Team & 2 & Technician \\
\hline Back-up Team & 2 & Technician \\
\hline Decon Team & 2 & Operations \\
\hline Medical Group & 2 & Operations and EMT \\
\hline Total & 12 & \\
\hline
\end{tabular}

Level Two incidents are those incidents in which operational actions must be taken to stabilize the situation and that require staffing levels greater than typically provided on the initial response. Level Two incidents require personnel trained to the Technician Level and supervisory personnel trained to the Specialist Level ${ }^{57}$ (California Hazardous Materials Specialist Certification). Minimum staffing for a Level II incident is determined to be the following:

Table 7.4.1-2 Level Two HAZMAT Staffing

\begin{tabular}{|l|c|l|}
\hline \multicolumn{1}{|c|}{ Task } & Staffing & \multicolumn{1}{c|}{ Training Level } \\
\hline Incident Commander & 1 & Hazmat. IC \\
\hline Hazmat Group Supervisor & 1 & Specialist \\
\hline Hazmat Safety & 1 & Specialist \\
\hline Technical Reference & 2 & Technician \\
\hline Entry Team Leader & 1 & Technician \\
\hline Entry Team & 2 & Technician \\
\hline Back-up Team & 2 & Technician \\
\hline Entry Team Time Recorder & 1 & Operations \\
\hline Decon Team Leader & 1 & Technician \\
\hline Decon Team & 2 & Operations \\
\hline Site Access Team Leader & 1 & Operations \\
\hline Medical Group & 2 & Operations and EMT qualified \\
\hline & 17 & \\
\hline
\end{tabular}

There are no specific response time criteria established by NFPA 1710 for hazardous materials incidents, so no specific response criteria is demanded by that standard, however, it is expected that the engine company assigned to LLNL will respond to the area of the hazardous materials incident in a timely manner, assuming there is a safe route of travel, so that the incident can be isolated and entry to the area can be denied to avoid injuries or contamination. The structure fire response time will be used for the initial and Level One responses only. Level Two responses are considered beyond initial attack and no specific response times are assigned or required. Site 300, because of its low inventory of hazardous materials as defined in Doe 151.1C is not evaluated for Level One response. 


\subsubsection{Minimum Requirements - HAZMAT}

Based on the requirements of NFPA 1710, OSHA 1910.120 and NFPA 472 and 473, the minimum performance measure for a Level 1 Hazardous Materials incident is established as follows:

Provide initial response to a hazardous materials incident at Site 200, Sandia/CA, and the Site 300 General Services Areas to arrive within a Total Response Time of 380 seconds $90 \%$ of the time and provide for a Level One response at Site 200 within a Total Response Time of 680 seconds $90 \%$ of the time.

Provide sufficient personnel trained to the proper level for a Level I or Level II hazardous materials incident prior to beginning any operations activities.

\subsubsection{Requirements Summary - HAZMAT}

\begin{tabular}{|c|c|c|}
\hline Task & Staffing & Training Level \\
\hline \multicolumn{3}{|c|}{ Investigation Level Incident } \\
\hline $\begin{array}{l}\text { Incident Commander } \\
\text { HazMat Group }\end{array}$ & $\begin{array}{l}1 \\
3\end{array}$ & $\begin{array}{l}\text { Hazmat IC \& Technician } \\
\text { Awareness }\end{array}$ \\
\hline Total & 4 & 380 sec. $90 \%$ of the time \\
\hline \multicolumn{3}{|c|}{ Level I Incident Site 200 Only } \\
\hline Incident Commander & 1 & Hazmat IC \& Specialist \\
\hline Safety and Tech Reference & 2 & HM Safety and Technician \\
\hline HazMat Group & 7 & Technician \\
\hline Medical Group & 2 & Operations \& EMT \\
\hline Total & 12 & 680 sec. $90 \%$ of the time \\
\hline \multicolumn{3}{|c|}{ Level II Incident Site 200 Only } \\
\hline Incident Commander & 1 & Hazmat IC \& Specialist \\
\hline Safety and Tech Reference & 3 & Specialists \& Technicians \\
\hline HazMat Group & 9 & Technician \& Operations \\
\hline Time Recorder \& Access Control & 2 & Operations \\
\hline Medical Group & 2 & Operations and EMT \\
\hline Total & 17 & \\
\hline
\end{tabular}

\subsection{Technical Rescue Response Requirements}

\subsubsection{Determination of Minimum Requirements - Technical Rescue}

The LLNL and Sandia campuses contain unique buildings and structures used for a variety of experimental purposes. Areas such as confined spaces, tall buildings, specially constructed test chambers, radioactively contaminated rooms and test chambers, explosive test chambers, and other one-of-a-kind structures can present unusual rescue problems after an accident.

DOE Order 420.1B and DOE G-420.1-3 discuss the need for DOE contractors to have a timely and effective response to a spectrum of emergency conditions that they encounter, including technical rescue. ${ }^{58}$ LLNL policy states that the Fire Department is the first responder to all emergency incidents other than security incidents. 
There are several federal requirements for responses to confined space incidents (29CFR1910.120 and 29CFR1910.146) which form the basis for those responses. NFPA 1670 Standard on Operations and Training for Technical Search and Rescue Incidents ${ }^{59}$ establishes the training requirements for other technical rescue incidents.

NFPA 1670 categorizes responses and the training and staffing necessary for those responses based on the hazard presented. The training necessary to respond to the various hazards is divided into three categories, Awareness, Operations, and Technician. The various types of technical rescue incidents (structural collapse, rope rescue, confined space search and rescue, vehicle and machinery search and rescue, wilderness search and rescue, and trench and excavation search and rescue) base staffing on the confined space search and rescue scenario. Staffing for an Operations Level confined space search and rescue incident is established at four persons, ${ }^{60}$ while staffing for a Technician Level confined space search and rescue is established at six persons. ${ }^{61}$

Staffing requirements will vary depending upon the type of technical rescue, however LLNL minimum staffing is based on an Operations Level incident that requires an Incident Command and four qualified personnel and a Technician Level incident that requires an Incident Commander and six qualified personnel based on NFPA 1670. For purposes of this BNA, a Technician Level Incident will be used to create the minimum response criteria. Response times will be based on times for a structural fire.

\subsubsection{Minimum Requirements - Technical Rescue}

Based on the requirements of OSHA 29CFR1910.120, 29CFR1910.146 and NFPA 1670, the minimum performance measure for a Technical Rescue incident is established as follows:

Respond to reported technical rescue incidents to at Site 200, Sandia/CA, and the GSA Area of Site 300 within a total response time of 380 seconds for the first arriving unit $90 \%$ of the time and with the remainder of the alarm assignment to arrive within a total response time of 1800 seconds $90 \%$ of the time.

Respond to reported technical rescue incidents Outside of the GSA Areas of S-300 within a total response time of 960 seconds for first arriving unit $90 \%$ of the time and with the remainder of the alarm assignment to arrive within a total response time of 2760 seconds $90 \%$ of the time.

\subsubsection{Requirements Summary - Technical Rescue}

Table 7.5.3 Requirements Summary - Technical Rescue

\begin{tabular}{|l|l|c|c|c|}
\hline \multicolumn{1}{|c|}{ Type Incident } & \multicolumn{1}{|c|}{ Responders } & $\begin{array}{c}\text { Minimum } \\
\text { Staffing } \\
\text { (persons) }\end{array}$ & $\begin{array}{c}\text { Total } \\
\text { Response } \\
\text { Time }\end{array}$ & $\begin{array}{c}\text { Performance } \\
\text { Criteria }\end{array}$ \\
\hline $\begin{array}{l}\text { S-200, Sandia/CA } \\
\begin{array}{l}\text { GSA Area S-300 } \\
\text { Technical Rescue }\end{array}\end{array}$ & $1^{\text {st }}$ Unit & 4 & 380 sec. & $90 \%$ \\
\cline { 2 - 5 } $\begin{array}{l}\text { Non GSA Area } \\
\text { Technical Rescue }\end{array}$ & $1^{\text {st }}$ Unit & 5 & 1800 sec. & $90 \%$ \\
\cline { 2 - 5 } & Remainder of $1^{\text {st }}$ Alarm & 5 & 2760 sec. & $90 \%$ \\
\hline
\end{tabular}




\subsection{Emergency Communication and Dispatch Requirements}

\subsubsection{Determination of Minimum Requirements - Emergency Communications}

The LLNL Fire and Emergency Voice Alarm (FEVA) system monitors fire alarms for LLNL, Lawrence Berkeley National Laboratory, Sandia/CA, and Parks Army Training Center. For the purposes of monitoring LLNL alarms, the system is considered a Remote Supervising Station System meeting the provisions of Section 8.5 of NFPA 72, National Fire Alarm and Signaling Code.

The LLNL system maintains a database of alarm points for all sites and reports as much detailed alarm information as is available from the remote system. During normal working hours, the LLNL Alarms Center (Lab Alarms) monitors the alarms from the various sites, participates in alarm testing for the various sites by acknowledging and validating tests, maintains and updates the database of alarm points, and passes actual alarms to the Alameda County Regional Emergency Communications Center (ACRECC) for emergency dispatch. During off hours, ACRECC monitors the LLNL Alarm System (which includes alarms from the other agencies), and dispatches emergencies. To avoid unnecessary delay in alarm processing, alarms are automatically sent to ACRECC for emergency dispatch within 45 seconds of receipt at Lab Alarms. This minimum delay allows Lab Alarms to intercept alarm tests and prevent unnecessary emergency dispatch.

Performance standards contained in NFPA 72 require that alarms signals shall be retransmitted to the fire department immediately; the automatic transmission of alarms to the dispatch screen satisfies this requirement. The maximum 45-second delay is judged to be less than that required to retransmit the alarm by another means. Remote supervising station systems are also required to monitor and notify appropriate personnel of supervisory signals and trouble signals. During normal LLNL working hours supervisory and trouble alarm processing is done by Lab Alarms with off hours monitoring and notification by ACRECC.

LLNL does not have augmented 911 service as part of their telephone switch, instead the switch allows the use of an alias, 911, to send calls to the original LLNL emergency number, 3-7333. Lab 911 calls are answered in the ACRECC center with ALI (automatic location identifier) and ANI (automatic number identifier) information displayed on the Lab Alarm Screen. Any security emergency call is routed to the LLNL Protective Force. Sandia/CA's security force answers 911 emergency phone calls at their central alarm station (CAS) for calls from their campus using a similar alias system and transfers the call to ACRECC if it is a fire or EMS incident.

ACRECC is Alameda County's regional emergency communications center serving communities, fire departments, and the Alameda County Emergency Medical Services Agency who are members of the ACRECC consortium agreement. The center was operated by the LLNL Fire Department until January of 2008, when the center's operation was turned over to the Alameda County Fire Department. The modern center is securely located in B-313 on the secure LLNL campus. 
As a fire department emergency communications center, ACRECC is expected to meet the requirements of NFPA 1221, Standard for the Installation, Maintenance, and Use of Emergency Services Communications Systems. The provisions of NFPA 1221 establish the minimum call handling criteria for receipt of alarm and dispatch of emergencies. Those performance requirements are:

- $95 \%$ of incoming emergency calls or alarms are answered within 15 seconds

- $99 \%$ of incoming emergency calls or alarms are answered within 40 seconds

- 90\% of alarms are dispatched within 60 seconds

- $99 \%$ of alarms are dispatched with 90 seconds

The provisions of NFPA 1221 establish the minimum call handling criteria for receipt of alarm and dispatch of emergencies. The provisions of NFPA 72 are not specific for handling of supervisory and trouble signals. Recognizing the procedures utilized by LLNL for these events, a minimum performance criterion of 10 minutes for notification of an appropriate party was chosen as the minimum performance criteria.

The minimum staffing for a center providing emergency medical dispatching is two persons at all times. Additional staffing is based on meeting the performance criteria.

Further, NFPA 1221 provides that dispatchers meet the qualifications provisions of NFPA 1061, Standard for Professional Qualifications for Public Safety Telecommunicator and certain other general requirements contain in Section 7.2 of NFPA 1221.

Additionally the dispatch center shall have the following capabilities:

- Record keeping system for all events including times of alarm receipt, dispatch, dispatch acknowledgement, enroute time, arrival time, patient contact time, and return to service time.

- Written operating procedures

- Written communications plan

- TDD/TTY capability

- Logging voice recorder

- Instant playback recorder of radio and phone conversations

- Emergency power

- Redundant radio communications capabilities

DOE Order 420.1B specifically mentions the ability of the fire fighting force to have radio communications capability with mutual aid resources.

\subsubsection{Minimum Requirements - Emergency Communications}

Based on the above analysis the minimum performance measures for Emergency Communications are as follows:

ACRECC shall provide evidence that their dispatch staff is trained to meet the qualifications of NFPA 1061 and is capable of meeting the provisions of Section 7.2 of NFPA 1221.

ACRECC shall provide evidence that alarms received, via telephone or alarms from $L L N L$ 's site-wide alarm system, are answered or in the case of signals from the 
alarm system, acknowledged, within 15 seconds $95 \%$ of the time and within 40 seconds $99 \%$ of the time.

ACRECC shall provide evidence that LLNL alarms are dispatched within 60 seconds $95 \%$ of the time and within 90 seconds $99 \%$ of the time.

Lab Alarms shall provide evidence that alarms are transmitted to ACRECC for dispatch within 45 seconds of receipt by Lab Alarms 95\% of the time.

ACRECC and/ Lab Alarms will notify the appropriate party within 10 minutes of a supervisory or trouble alarm 95\% of the time to allow for response of appropriate personnel.

\subsubsection{Requirements Summary - Emergency Communications}

Table 7.6.3 Requirements Summary - Emergency Communications

\begin{tabular}{|l|c|c|}
\hline \multicolumn{1}{|c|}{ Event } & Time Criteria & Performance \\
\hline Dispatcher training & N/A & NFPA 1061 \\
\hline ACRECC Answer or & 15 seconds & $95 \%$ \\
Acknowledge Alarm & 40 seconds & $99 \%$ \\
\hline ACRECC Dispatch & 60 seconds & $95 \%$ \\
Emergency & 90 seconds & $99 \%$ \\
\hline Lab Alarms transmit alarms to & 45 seconds & $95 \%$ \\
ACRECC & & \\
\hline ACRECC and/or Lab Alarms & 600 seconds & $95 \%$ \\
Notify Appropriate Party of & & \\
Supervisory or Trouble Alarm & & \\
\hline
\end{tabular}

\subsection{Training and Certification}

\subsubsection{Determination of Minimum Requirements - Training}

All the requirement documents state that there needs to have a trained emergency response organization. The references in DOE 420.1B and 10CFR 851 refer to use of the applicable NFPA codes and standards as well as training necessary to understand the site hazards, building layouts, site emergency plans, and any special fire fighting instructions, such as limitations on the use of water as an extinguishing agent. DOE 151.1C requires a coordinated program of training, drills, and exercises to be able to respond to the various emergencies on the LLNL site. In addition, training is required to meet OSHA requirements.

The various DOE references to NFPA codes and standards result in application of the following NFPA standards as a minimum:

- NFPA 472, Standard for Professional Competence of Responders to Hazardous Materials Incidents, 2008 Edition.

- NFPA 473, Standard for Competencies for EMS Personnel Responding to Hazardous Materials Incidents, 2008 Edition 
- NFPA 1001, Standard for Fire Fighter Professional Qualifications, 2008 Edition.

- NFPA 1002, Standard on Fire Apparatus Driver/Operator Professional Qualifications, 2009 Edition.

- NFPA 1021, Standard for Fire Officer Professional Qualifications, 2009 Edition.

- NFPA 1041, Standard for Fire Service Instructor Professional Qualifications, 2007 Edition

- NFPA 1051, Standard for Wildland Fire Fighter Professional Qualifications, 2007 Edition

- NFPA 1404, Standard for Fire Service Respiratory Protection Training, 2006 Edition.

- NFPA 1403, Standard on Live Fire Training Evolutions, 2007 Edition.

- NFPA 1670, Standard on Operations and Training for Technical Rescue Incidents, 2009 Edition.

Further, a written training policy, program, and documentation that training has been completed is required as well as a refresher-training schedule and task performance evaluations. Site-specific training is also required particularly for specific hazards, such as radiation hazards, biological hazards, and chemical hazards.

\subsubsection{Minimum Requirements - Training}

Based on the above requirement and analysis the minimum performance measures for Training are as follows:

Qualifications are established for entry-level fire department personnel that include medical and physical performance criteria.

There is an established training criterion for minimum performance of entry-level personnel.

There is an established on-going training criterion for training for incumbents.

There is a minimum training criteria established for fire officers or supervisors of emergency responder.

There is a minimum training criteria established for special operations such as hazardous materials and technical rescue.

There is an established program of drills and exercises at various facilities on LLNL site.

Documented training records exist for each individual. 


\subsubsection{Requirements Summary - Training}

Table 7.7.3 Requirements Summary - Training

\begin{tabular}{|l|l|}
\hline \multicolumn{1}{|c|}{ Personnel } & \multicolumn{1}{c|}{ Performance Measure } \\
\hline Entry level & $\begin{array}{l}\text { Qualifications are established for entry-level fire } \\
\text { department personnel that include medical and } \\
\text { physical performance criteria. }\end{array}$ \\
\hline Entry level & $\begin{array}{l}\text { There is an established training criterion for } \\
\text { minimum performance of entry-level personnel. }\end{array}$ \\
\hline Incumbents & $\begin{array}{l}\text { There is an established on-going training criterion } \\
\text { for training for incumbents. }\end{array}$ \\
\hline Officers & $\begin{array}{l}\text { There is a minimum training criteria established for } \\
\text { fire officers or supervisors of emergency responder. }\end{array}$ \\
\hline Special Operations & $\begin{array}{l}\text { There is a minimum training criteria established for } \\
\text { special operations such as hazardous materials and } \\
\text { technical rescue. }\end{array}$ \\
\hline Drills and Exercises & $\begin{array}{l}\text { There is an established program of drills and } \\
\text { exercises at various facilities on LLNL site. }\end{array}$ \\
\hline All & $\begin{array}{l}\text { Documented training records exist for each } \\
\text { individual. }\end{array}$ \\
\hline
\end{tabular}

\subsection{Pre-Fire Plan Requirements}

\subsubsection{Determination of Minimum Requirements - Pre-Fire Plans}

DOE 420.1B, Facility Safety, requires that contractors provide an "improved risk" level of fire protection. One specific component of this level of protection is the maintenance of written pre-fire plans and standard operating procedures. ${ }^{62,63}$

DOE 151.1C, Comprehensive Emergency Management System, requires establishment and maintenance of plans and procedures for response to operational emergencies involving or affecting DOE facilities. 151.1C requires the preparation of Emergency Planning Hazards Assessments (EPHAs) which identify hazards and potential consequences from unplanned releases of hazardous materials (where quantities of hazardous materials exceed established screening thresholds) and provides protective actions for such releases.

All requirement documents discuss the need for written pre-fire plans, written policies, and operating procedures to assist in the emergency response. The minimum performance requirement is the development of pre-fire plans for all buildings on LLNL and Sandia/CA property. The format and contents of these plans should meet the provisions of LLNL Policy 310.00 Building and Trailer Run Cards and the needs of the emergency responders from the Alameda County Fire Department. LLNL Fire Department Procedure 310.00 has been re-issued as an ACFD Policy, Policy 30-103. NFPA 1620 Recommended Practice for Pre-Incident Planning ${ }^{64}$ provides a possible format for preplans. 


\subsubsection{Minimum Requirements - Pre-Fire Plans}

Pre-fire plans shall exist for all LLNL and Sandia/CA buildings as well as an established policy to ensure that the LLNL pre-plans are accurate and updated at least annually. Sandia/CA pre-plans are updated annually. In addition, written standard operations procedures for emergency response to the various hazards encountered at LLNL buildings are required. LLNL policy is to have the Special Information Sheets and Emergency Call Out Lists updated quarterly by the ES\&H Teams. The performance criteria for Pre-Fire Plans are as follows:

Provide pre-fire plans for all LLNL and Sandia/CA buildings meeting LLNL Procedure 310.00 with a semi-annual review frequency to ensure that they are current and accurate.

Provide and maintain written standard operating procedures for emergency response to occupancies with hazardous materials or other unique hazards.

Ensure that Emergency Call Out Lists and Special Information Sheets are updated Quarterly by ES\&H Teams.

\subsubsection{Requirements Summary - Pre-Fire Plans}

Table 7.8.3 Requirements Summary - Pre-Fire Plans

\begin{tabular}{|l|c|}
\hline \multicolumn{1}{|c|}{ Performance Measure } & Update Frequency \\
\hline Provide pre-fire plans for all buildings & Semi-Annual \\
\hline $\begin{array}{l}\text { Provide written standard operating procedures for } \\
\text { response to occupancies with hazardous materials or } \\
\text { other unique hazards }\end{array}$ & $\begin{array}{l}\text { Review Annually - } \\
\text { Update as Needed. }\end{array}$ \\
\hline $\begin{array}{l}\text { Ensure that Emergency Call Out Lists and Special } \\
\text { Information Sheets are updated by ES\&H Teams. }\end{array}$ & Quarterly \\
\hline
\end{tabular}

\subsection{Emergency Response Apparatus Requirements}

\subsubsection{Determination of Minimum Response Requirements - Apparatus}

To perform its function, the fire department must be equipped with the necessary fire apparatus and equipment. Typically, this will involve the purchase of specialized emergency response vehicles suitable to the hazards present and to the duties of the fire department.

Engines (sometimes called pumpers because they pump water) are the fundamental tactical unit of a fire department. Engines are versatile and respond to every incident. In California ICS terminology, engines are categorized by Type, which describes their characteristics and capability. This categorization is as follows: 
Table 7.11.2-1 California ICS Apparatus Type Description

\begin{tabular}{|c|c|c|}
\hline Apparatus Type & Characteristics & Minimum Requirements \\
\hline Type 1 Engine & Structural & $\begin{array}{l}\text { 1,000 gpm pump } \\
400 \text { gal tank } \\
1,200 \mathrm{ft} .2-1 / 2 \text { inch hose } \\
400 \mathrm{ft}-1-1 / 2 \text { inch hose } \\
500 \mathrm{gpm} \text { master stream device }\end{array}$ \\
\hline Type 2 Engine & $\begin{array}{l}\text { Limited Structural } \\
\text { Vehicle/Rescue } \\
\text { Limited Wildland }\end{array}$ & $\begin{array}{l}500 \text { gpm pump } \\
400 \text { gal tank } \\
1,000 \mathrm{ft} .2-1 / 2 \text { inch hose } \\
500 \mathrm{ft}-1-1 / 2 \text { inch hose }\end{array}$ \\
\hline Type 3 Engine & $\begin{array}{l}\text { Heavy Wildland } \\
\text { Short Wheelbase } \\
\text { Short After Axle } \\
\text { High Ground Clearance } \\
\text { Often 4X4 }\end{array}$ & $\begin{array}{l}\text { 120gpm pump } \\
300 \text { gal tank } \\
1,000 \mathrm{ft} .1-1 / 2 \text { inch hose } \\
800 \mathrm{ft}-1 \text { inch hose }\end{array}$ \\
\hline Type 4 Engine & $\begin{array}{l}\text { Light Wildland } \\
\text { 4X4 } \\
\text { Skid Load Pump } \\
\text { Module } \\
\end{array}$ & $\begin{array}{l}50 \text { gpm Pump } \\
200 \text { gal tank } \\
300 \mathrm{ft.} 1-1 / 2 \text { inch hose } \\
800 \mathrm{ft}-1 \text { inch hose } \\
\end{array}$ \\
\hline
\end{tabular}

Other, more specialized apparatus, may or may not be required depending upon the character of the area being protected. Aerial ladder apparatus is an example. The need for an aerial ladder is predicated on the number of tall buildings or structures. One guide for determining the number of aerial ladders was the "grading schedule" of the National Board of Fire Underwriters. That schedule, was used to evaluate municipal fire protection for the determination of insurance rates and for many years was the only guide on fire department organization, staffing, and operation. The original grading schedule recommended an aerial ladder if the area being served contained five buildings four or more stories in height. ${ }^{65}$ More current versions of the grading schedule have a more generalized requirement of being able to reach the roof of any building up to $100 \mathrm{ft}^{66}$

The fire department at LLNL provides emergency response to structure fires, vehicle fires, wildland fires, vehicle accidents, hazardous materials incidents, emergency medical incidents, and technical rescue incidents. In addition to emergency response, the fire department also conducts a prescribed burn of S-300 wildland fuel each spring. Routine functions include performing fire inspections, issuing open flame permits, and conducting sprinkler shutdowns and restorations. The following table describes the type of service provided and the appropriate apparatus for that service. 
Table 7.11.2-2 Apparatus Needs per Service Required

\begin{tabular}{|c|c|c|}
\hline Type Service & Type Apparatus & Basic Function \\
\hline Structure Fire & Type 1 Engine & $\begin{array}{l}\text { Fire Attack } \\
\text { Pump, Water, Hose }\end{array}$ \\
\hline Structure Fire & Aerial Ladder & $\begin{array}{l}\text { Rescue from heights, Access } \\
\text { to Roof, Elevated Master } \\
\text { Streams } \\
\text { Ladders, Rescue Tools, } \\
\text { Salvage Equip., Lights }\end{array}$ \\
\hline Vehicle Fire & Type 1 or 3 Engine & $\begin{array}{l}\text { Fire Attack } \\
\text { Pump, Water, Hose }\end{array}$ \\
\hline Wildland Fire & Type 3 or 4 Engine & $\begin{array}{l}\text { Fire Attack } \\
\text { Pump, Water, Hose, Off } \\
\text { road capability. }\end{array}$ \\
\hline Vehicle Accident & Engine, Any Type & $\begin{array}{l}\text { Fire Control } \\
\text { Pump, Water, Hose, } \\
\text { Extrication Capability }\end{array}$ \\
\hline $\begin{array}{l}\text { Emergency Medical } \\
\text { Incident requiring } \\
\text { transportation }\end{array}$ & Ambulance & $\begin{array}{l}\text { Emergency Medical Care } \\
\text { Emergency Transportation } \\
\text { ALS Medical Equipment }\end{array}$ \\
\hline $\begin{array}{l}\text { Hazardous Materials } \\
\text { Incident }\end{array}$ & Hazardous Materials Vehicle & $\begin{array}{l}\text { Evaluation of and } \\
\text { containment of Hazardous } \\
\text { Materials. } \\
\text { Protective suits, dike and } \\
\text { absorbing materials, analysis } \\
\text { capability. }\end{array}$ \\
\hline Technical Rescue & $\begin{array}{l}\text { Pumper } \\
\text { Aerial Ladder } \\
\text { Hazardous Materials Vehicle }\end{array}$ & $\begin{array}{l}\text { Stabilize Situation and } \\
\text { Extricate Victims }\end{array}$ \\
\hline Incident Command & Passenger Vehicle & $\begin{array}{l}\text { Command and Control } \\
\text { Off Road Capability }\end{array}$ \\
\hline $\begin{array}{l}\text { Inspection, Testing, } \\
\text { Permits, Shut downs }\end{array}$ & Passenger Vehicle & $\begin{array}{l}\text { Transportation } \\
\text { Carry necessary tools }\end{array}$ \\
\hline Controlled Burn S-300 & $\begin{array}{l}\text { Type } 3 \text { Engines (2) } \\
\text { Type } 4 \text { Engines (2) }\end{array}$ & $\begin{array}{l}\text { One of each can be used at } \\
\text { each station for normal } \\
\text { response to wildland fires }\end{array}$ \\
\hline
\end{tabular}

Given the types of emergencies, services provided, and the staffing requirements derived in other sections of this analysis the following table contains the minimum apparatus necessary to meet the demands imposed on the Fire Department at LLNL. The need for aerial ladder apparatus is a function of building height. 
Table 7.11.2-3 LLNL Apparatus Requirements

\begin{tabular}{|c|c|c|c|c|}
\hline Site & Service & Apparatus & Number & Comment \\
\hline Livermore & $\begin{array}{l}\text { Structure Fire } \\
\text { Vehicle Fire } \\
\text { Vehicle Accident } \\
\text { Technical Rescue }\end{array}$ & Type 1 Engine & 2 & $\begin{array}{l}\text { Two company fire attack } \\
\text { Response to simultaneous } \\
\text { incidents }\end{array}$ \\
\hline Livermore & $\begin{array}{l}\text { Structure Fire } \\
\text { Technical Rescue }\end{array}$ & Aerial & 1 & $\begin{array}{l}\text { When required. } \\
\text { Can be part of two piece } \\
\text { engine company }\end{array}$ \\
\hline Livermore & Wildland Fire & Type 4 Engine & 1 & $\begin{array}{l}\text { Responds Livermore Site } \\
\text { Required for Controlled } \\
\text { Burn at Site } 300 .\end{array}$ \\
\hline Livermore & Emergency Medical & Ambulance & 1 & \\
\hline $\begin{array}{l}\text { Livermore } \\
\text { Site } 300\end{array}$ & Hazardous Materials & HazMat & 1 & \\
\hline $\begin{array}{l}\text { Livermore } \\
\text { Site } 300\end{array}$ & Incident Command & Command & 1 & Battalion Chief \\
\hline Livermore & $\begin{array}{l}\text { Inspection } \\
\text { Fire Extinguishers } \\
\text { Alarm Testing } \\
\end{array}$ & Passenger & 3 & $\begin{array}{l}\text { Fire Prevention Techs. } \\
\text { Reserve Command } \\
\text { Vehicles }\end{array}$ \\
\hline Site 300 & $\begin{array}{l}\text { Structure Fire } \\
\text { Vehicle Fire } \\
\text { Vehicle Accident } \\
\text { Technical Rescue }\end{array}$ & Type 1 Engine & 1 & $\begin{array}{l}\text { Second pumper responds } \\
\text { from Livermore }\end{array}$ \\
\hline Site 300 & Wildland Fire & $\begin{array}{l}\text { Type } 3 \text { Engine } \\
\text { Type } 4 \text { Engine }\end{array}$ & $\begin{array}{l}1 \\
1 \\
\end{array}$ & \\
\hline Site 300 & Prescribed Burn & $\begin{array}{l}\text { Type } 3 \text { Engine } \\
\text { Type } 4 \text { Engine }\end{array}$ & $\begin{array}{l}2 \\
2\end{array}$ & \\
\hline Site 300 & Emergency Medical & Ambulance & 1 & \\
\hline
\end{tabular}

Certain emergency apparatus is critical to providing a response capability. Those units must be provided with readily available back-ups to allow for breakdowns and routine maintenance. There is no national standard for ratio of reserve apparatus to apparatus in front-line service. The type and complexity of apparatus, number of responses, and degree of preventive maintenance being performed will dictate the number and type of breakdowns. It is clear that there will be breakdowns and routine maintenance; therefore, some number of reserve apparatus must be available. A historic guide for reserve apparatus was a ratio of one reserve pumper for every 8 pumpers in front-line service. ${ }^{67} \mathrm{~A}$ more modern rule of thumb is one reserve for every 5 in front-line service. This same rule can be applied to wildland pumpers and ambulances. It is not appropriate to apply the reserve ratio to unique or specialized apparatus such as hazardous materials units. Single aerial apparatus are typically not provided with a reserve, especially if another aerial apparatus is available via mutual or automatic aid.

The following table summarizes the determined minimum reserve apparatus. 
Table 7.11.2-4 Reserve Apparatus Requirements

\begin{tabular}{|c|c|l|}
\hline Type & Number & \multicolumn{1}{c|}{ Comment } \\
\hline Type 1 Engine & 1 & 1 Reserve per 5 in front-line service. \\
\hline Ambulance ALS & 1 & 1 Reserve per 5 in front-line service. \\
\hline Type 3 or 4 Engine & 1 & 1 Reserve per 5 in front-line service. \\
\hline
\end{tabular}

An apparatus replacement program must be in place to insure the fire department is equipped with reliable modern apparatus. Historic guidance for apparatus replacement was 20 years in front-line service and 5 years in reserve. The complexity of modern apparatus and the frequency of technology change dictate a more frequent replacement schedule. Removal from font-line service at 15 years with a potential for 5 years of reserve service is a realistic goal for engines. Heavily used aerial ladder apparatus would follow the same schedule where lightly used aerials, such as that of LLNL, would be removed from frontline service at 20 years. ${ }^{68}$ Emergency vehicles such as ambulances, wildland patrols, and hazardous materials need to be replaced on a more frequent schedule, depending upon maintenance, use, and condition of the apparatus. A replacement schedule, such as that recommended by the General Services Administration, can be a useful planning guide. Detailed records of repairs, use, and replacement needs will allow the development of an organization-specific replacement schedule.

\subsubsection{Minimum Requirements - Apparatus}

Provide the following apparatus for use by the Fire Department at LLNL:

\begin{tabular}{|c|c|c|}
\hline Type Apparatus & Number & Comment \\
\hline Engine & 3 & Livermore Site - 2, S-300-1 \\
\hline Aerial Ladder & 1 & Livermore Site \\
\hline $\begin{array}{l}\text { Ambulance ALS } \\
\text { Configuration }\end{array}$ & 2 & Livermore Site - 1, S-300-1 \\
\hline Type 3 Engine & 2 & Livermore Site - 1, S-300-1 \\
\hline Type 4 Engine & 2 & Livermore Site - 1, S-300-1 \\
\hline Hazardous Materials & 1 & Responds both sites \\
\hline Command & 1 & Battalion Chief \\
\hline Reserve Type 1Engine & 1 & 1 Reserve per 5 in front-line service \\
\hline Reserve Ambulance & 1 & 1 Reserve per 5 in front-line service \\
\hline Reserve Type 3 Engine & 1 & 1 Reserve per 5 in front-line service \\
\hline Reserve Type 4 Engine & 1 & 1 Reserve per 5 in front-line service \\
\hline
\end{tabular}

Apparatus and equipment must meet NFPA Standards for design, minimum equipment, and maintenance.

Provide a written replacement schedule for all emergency apparatus to allow timely replacement.

\subsubsection{Requirements Summary - Apparatus}

Table 7.11.4 LLNL Required First Line and Reserve Apparatus

\begin{tabular}{|l|c|l|}
\hline \multicolumn{1}{|c|}{ Type Apparatus } & Number & \multicolumn{1}{c|}{ Comment } \\
\hline Engine & 3 & Livermore Site -2, S-300 - 1 \\
\hline Aerial Ladder & 1 & Livermore Site \\
\hline Ambulance & 2 & Livermore Site - 1, S-300 - 1 \\
\hline
\end{tabular}




\begin{tabular}{|l|c|l|}
\hline \multicolumn{1}{|c|}{ Type Apparatus } & Number & \multicolumn{1}{c|}{ Comment } \\
\hline Type 3 Engine & 2 & Livermore Site - 1, S-300 - 1 \\
\hline Type 4 Engine & 2 & Livermore Site - 1, S-300 - 1 \\
\hline Hazardous Materials & 1 & Responds both sites \\
\hline Command & 1 & Battalion Chief \\
\hline Reserve Type 1Engine & 1 & 1 Reserve per 5 in front-line service \\
\hline Reserve Ambulance & 1 & 1 Reserve per 5 in front-line service \\
\hline Reserve Type 3 Engine & 1 & 1 Reserve per 5 in front-line service \\
\hline Reserve Type 4 Engine & 1 & 1 Reserve per 5 in front-line service \\
\hline Apparatus Plan & & Written 5 year Plan \\
\hline Apparatus Maintenance & & Per NFPA and GSA Fleet Requirements \\
\hline
\end{tabular}

\section{Biographies of Principal Authors}

John A. Sharry. Mr. Sharry is the current LLNL Fire Marshal and was the Division Leader for Emergency Management and Fire Chief of Lawrence Livermore National Laboratory from 1981 until his retirement in 2002. Prior to joining LLNL in 1981, Mr. Sharry held positions as Assistant Director of Engineering Service and Chief Life Safety Code Specialist for the National Fire Protection Association (NFPA). Early in his career Mr. Sharry served as an field engineer for the National Board of Fire Underwriters and the Fire Insurance Rating Organization of New Jersey, Director of Fire Technology Programs for Delaware Technical and Community College, Fire Investigator for NFPA, Chief Fire Marshal of Prince William County Virginia, and engineering manager positions with Code Consultants Inc. and Hughes Associates, Inc. Mr. Sharry is a Certified Chief Fire Officer and Fire Prevention Officer. He holds a Bachelor's Degree (University of Maryland 1970) and is finishing his Master's Degree in Public Administration (University of Southern California).

Mr. Sharry has served as Chair of the NFPA Technical Committee on Fire Department Occupational Safety and Health (NFPA 1500), Chair of the Technical Committee on Assembly and Educational Occupancies, and Chair of the Technical Committee on Residential Occupancies. He has been a member of the Technical Committees on Means of Egress, Fire Department Risk Management, Disaster/Emergency Management and Business Continuity and is currently a member of the Technical Committees on Residential Occupancies, Uniform Fire Code, and alternate member on the Technical Correlating Committee on Fire and Emergency Service Protective Clothing and Equipment. He was honored in 1989 to be named to NFPA Standard Council, a position he held for two consecutive 3 year terms. Mr. Sharry is the author of many articles on fire protection and is the author of the first edition of Life Safety Code Handbook and contributing author to the second through fourth editions of that handbook. He has been a contributing author to many editions of the Fire Protection Handbook and the technical editor and sometime performer in several fire protection educational films.

Mr. Sharry continues as the senior instructor in the NFPA's seminar program. He developed and taught the first Life Safety Code seminar in 1977, a program in which he continues as an instructor. Mr. Sharry also instructs for the NFPA seminars on Fire Protection Equipment Maintenance and Emergency Planning. Mr. Sharry has extensive 
experience in code enforcement and applications of codes and standards to a variety of occupancies and in developing fire department baseline needs analyses.

Martin Gresho, PE. Mr. Gresho is a registered professional Fire Protection Engineer (CA1989) with experience in both the nuclear (commercial nuclear power reactors and DOE nuclear facilities) and the commercial sectors of fire protection and code enforcement. Mr. Gresho has performed Fire Hazards Analyses for numerous nuclear facilities. Mr. Gresho serves as the Fire Marshal at Sandia National Laboratory's California site with oversight responsibility for all fire protection systems and code compliance site-wide. Mr. Gresho also serves on several NFPA Technical Committees charged with development of new code (NFPA 2 Hydrogen - Chair; NFPA 55 Industrial and Medical Gases - Principal; NFPA 400 Hazardous Materials - Principal). Mr. Gresho has experience as both a FPE and a Licensing Engineer in the NRC Regulated nuclear power industry. Mr. Gresho has a master's degree in Environmental Engineering (1995) and a Bachelor's Degree in Mechanical Engineering (1985). 
${ }^{1}$ U.S. Department of Energy, DOE Model Fire Protection Baseline Capabilities, [cited February 25, 2008] available from http://www.tis.eh.doe.gov/fire/models/baseline.pdf.

${ }^{2}$ Master Emergency Program Plan (MEPP) for Lawrence Berkeley National Laboratory, LBNL-PUB-533209 Revision 4, September 30, 2009.

${ }^{3}$ U.S. Department of Energy, Facility Safety Order, DOE 420.1B, Attachment 2, 12/22/2005, Chapter II.

${ }^{4}$ DOE 151.1C, Comprehensive Emergency Management System, November 2, 2005.

${ }^{5}$ National Fire Protection Association, Standard for the Installation of Sprinkler Systems, NFPA 13, Quincy, MA: 2010

${ }^{6}$ National Fire Protection Association, National Fire Alarm and Signaling Code, NFPA 72, Quincy, MA: 2010.

${ }^{7}$ National Fire Protection Association, Standard for Professional Competence of Responders to Hazardous Materials/Weapons of Mass Destruction Incidents, NFPA 472, Quincy, MA: 2008.

${ }^{8}$ National Fire Protection Association, Standard for Competencies for EMS Personnel Responding to Hazardous Materials/Weapons of Mass Destruction Incidents, NFPA 473, Quincy, MA: 2008.

${ }^{9}$ National Fire Protection Association, Standard for Fire Fighter Professional Qualifications, NFPA 1001, Quincy, MA: 2008.

${ }^{10}$ National Fire Protection Association, Standard on Fire Apparatus Driver/Operator Professional Qualifications, NFPA 1002, Quincy, MA: 2009.

${ }^{11}$ National Fire Protection Association, Standard for Rescue Technician Professional Qualifications, NFPA 1006, Quincy, MA: 2008.

${ }^{12}$ National Fire Protection Association, Standard on Fire Officer Professional Qualifications, NFPA 1021, Quincy, MA: 2009.

${ }^{13}$ National Fire Protection Association, Standard for Wildland Fire Fighter Professional Qualifications, NFPA 1051, Quincy, MA: 2007.

${ }^{14}$ National Fire Protection Association, Standard for Professional Qualifications for Public Safety Telecommunicator, NFPA 1061, Quincy, MA: 2007.

${ }^{15}$ National Fire Protection Association, Standard for the Installation, Maintenance, and Use of Emergency Services Communications Systems, NFPA 1221, Quincy, MA: 2010.

${ }^{16}$ National Fire Protection Association, Standard for Fire Service Respiratory Protection Training, NFPA 1404, Quincy, MA: 2006.

${ }^{17}$ National Fire Protection Association, Standard on Live Fire Training Evolutions, NFPA 1403, Quincy, MA: 2007.

${ }^{18}$ National Fire Protection Association, Standard for Fire Department Occupational Safety and Health Program, NFPA 1500, Quincy, MA: 2007, Paragraph 8.4.7.

${ }^{19}$ National Fire Protection Association, Standard for Fire Department Safety Officer, NFPA 1521, Quincy, MA: 2008.

${ }^{20}$ National Fire Protection Association, Standard on Emergency Service Incident Management System, NFPA 1561, Quincy, MA: 2008.

${ }^{21}$ National Fire Protection Association, Standard on Comprehensive Occupational Medical Program for Fire Departments, NFPA 1582, Quincy, MA: 2007.

${ }^{22}$ National Fire Protection Association, Standard on Operations and Training for Technical Rescue Incidents, NFPA 1670, Quincy, MA: 2009.

${ }^{23}$ National Fire Protection Association, Standard for the Organization and Deployment of Fire Suppression Operations, Emergency Medical Operations, and Special Operations to the Public by Career Fire Departments, NFPA 1710, Quincy, MA: 2010.

${ }^{24}$ National Fire Protection Association, Standard for Automotive Fire Apparatus, NFPA 1901, Quincy, MA: 2009.

${ }^{25}$ National Fire Protection Association, Standard for Wildland Fire Apparatus, NFPA 1906, Quincy, MA: 2006.

${ }^{26}$ National Fire Protection Associations, Standard for the Inspection, Maintenance, Testing, and Retirement of In-Service Automotive Fire Apparatus, NFPA 1911, Quincy, MA: 2007.

${ }^{27}$ DOE Implementation Guide for DOE Fire Protection and Emergency Services Programs, G 420.1-3, 9-2707, Paragraph 4.9-6. 
${ }^{28}$ DOE G 440.1-8, Implementation Guide for use with 10 CFR 851 Worker Safety and Health Program, 1227-06, [cited August 8, 2009] available from: http://www.directives.doe.gov/pdfs/doe/doetex/neword/ 440/ g4401-8.pdf.

${ }^{29}$ DOE STD 1066-99, Fire Protection Design Criteria, July, 1999.

${ }^{30}$ DoD Instruction 6055.06, DoD Fire and Emergency Services (F\&ES) Program, December 21, 2006.

${ }^{31}$ National Fire Protection Association, Recommended Practice for Pre-Incident Planning, NFPA 1620, Quincy, MA: 2003.

${ }^{32}$ National Fire Protection Association, Standard for Fire Department Occupational Safety and Health Program, NFPA 1500, Quincy, MA: 2007, Paragraphs 3.3.34 and A.3.3.34.

${ }^{33}$ DOE Order 420.1B, Facility Safety, 12-22-07, Chapter II, Section 3b (7).

${ }^{34}$ DOE G 420.1-3 Section 3b(8).

${ }^{35}$ National Fire Protection Association, Standard for the Installation of Automatic Sprinkler Systems, NFPA 13, Quincy, MA: 2010.

${ }^{36}$ National Fire Protection Association, Fire Protection Handbook, $19^{\text {th }}$ Edition, Quincy, MA: 2003, 3-137.

${ }^{37}$ Ibid. Paragraph A.5.2.2.2.1.

${ }^{38}$ Fire Protection Handbook, 2-79.

${ }^{39}$ U.S. Department of Energy, Automatic Sprinkler Performance and Reliability in United States Department of Energy Facilities 1952 - 1980, U. S. Department of Energy, DOE/EP—0052, 1982

${ }^{40}$ Fire Protection Handbook, 10-187.

${ }^{41}$ Hall, John R., U. S. Experience with Sprinklers and Other Automatic Fire Extinguishing Equipment, National Fire Protection Association, Quincy, MA: 2007, Pg. 25.

${ }^{44}$ Creating and Evaluating Standards of Response Coverage for Fire Departments, $4^{\text {th }}$. Edition, Center for Public Safety Excellence, Chantilly, VA: 2004.

${ }^{45}$ National Fire Protection Association, Standard for the Organization and Deployment of Fire Suppression Operations, Emergency Medical Operations, and Special Operations to the Public by Career Fire

Departments, NFPA 1710, Quincy, MA: 2010.

${ }^{46}$ Ibid., Paragraph A.5.2.3.2.1

${ }^{47}$ Ibid, Subsection 1.3.

${ }^{48}$ National Fire Protection Association, Standard on Fire Department Occupational Safety Program, NFPA 1500, Quincy, MA: 2002, Paragraph 8.4.23.

${ }^{49}$ NFPA 1710, Paragraph A.4.1.2.

${ }^{50}$ NFPA 1710, Section 5.7.

${ }^{51}$ NFPA 1710, Paragraph 5.3.3.4.

${ }^{52}$ National Fire Protection Association, Standard on Fire Department Occupational Safety Program, NFPA 1500, Quincy, MA: 2004, Paragraph 8.5.21.

${ }^{53}$ NFPA 1710, Paragraph 4.4.2.

${ }^{54}$ NFPA 472, Annex H.

${ }^{55}$ NFPA 472, Chapter 4.

${ }^{56}$ Ibid, Chapter 6.

${ }^{57}$ Ibid, Chapter 8.

${ }^{58}$ DOE G-420.1-3, Section 4.1 Program Objectives.

${ }^{59}$ National Fire Protection Association, Standard on Operations and Training for Technical Search and Rescue Incidents, NFPA 1670, 2009 Edition, Quincy, MA: 2004.

${ }^{60}$ NFPA 1670, Standard on Operations and Training for Technical Search and Rescue Operations, 2009 Edition, Section 7.3.2.

${ }^{61}$ Ibid, Section 7.4.2

${ }^{62}$ DOE 420.1B, Attachment 2, Chapter 2, 3b (10).

${ }^{63}$ DOE Fire Safety Program Implementation Guide, Section 4.8

${ }^{64}$ National Fire Protection Association, Recommended Practice for Pre-Incident Planning, Quincy, MA: 2003

${ }^{65}$ National Board of Fire Underwriters, Standard Schedule for Grading Cities and Towns of the United States with Reference to Their Fire Defenses and Physical Conditions, New York, NY: 1956, 51. 
${ }^{66}$ Insurance Services Office, Public Protection Classification Program, [electronic guide] (Jersey City, New Jersey) \{cited 13 March 2004\}, available from http://www.isomitigation.com/fire72.html\#18.

${ }^{67}$ Insurance Services Office, Fire Suppression Rating Schedule, Jersey City, NJ: 2003, 61.

${ }^{68}$ National Fire Protection Association, Fire Protection Handbook, $19^{\text {th }}$ Edition, Quincy, MA: 2003, 7-275. 